\title{
Proteases to die for
}

\author{
Vincent Cryns ${ }^{1}$ and Junying Yuan ${ }^{2,3}$ \\ ${ }^{1}$ Center for Endocrinology, M etabolism and Molecular M edicine, N orthwestern University School of Medicine, Chicago, \\ IIlinois 60611 USA; ${ }^{2}$ Department of Cell Biology, Harvard Medical School, Boston, Massachusetts 02115 USA
}

A poptosis or programmed cell death (PCD) is a genetically regulated, cellular suicide mechanism that plays a crucial role in devel opment and in the defense of homeostasis. Cells respond to a variety of disparate signals by committing suicide through a series of dramatic but remarkably uniform events. M orphologically, cells undergoing apoptosis demonstrate nuclear/cytoplasmic condensation and membrane protrusions. These initial changes are followed by fragmentation of the nuclear contents and subsequent encapsulation of these fragments into "apoptotic bodies" that are quickly and unobtrusively consumed by adjacent cells, thereby leaving little trace of the apoptotic cell's prior existence (Kerr et al. 1972). Biochemically, apoptotic cells are characterized by reduction in the mitochondrial transmembrane potential, intracellular acidification, production of reactive oxygen species, externalization of phosphatidylserine residues in membrane bilayers, selective proteolysis of a subset of cellular proteins, and degradation of DNA into internucleosomal fragments (Wyllie et al. 1984; Hockenbery et al. 1993; Lazebnik et al. 1994; Martin et al. 1995b; Gottlieb et al. 1996; Zamzami et al. 1996b). These characteristic manifestations of apoptosis reflect the activation of an intrinsic cell death apparatus that has been exquisitely conserved during evolution. At the core of this death apparatus is a novel family of proteases related to the Caenorhabditis elegans cell death gene product CED-3, the so-called caspases (cysteine proteases with aspartate-specificity), that are universal effectors of apoptotic cell death. Although several features of these pro-apoptotic proteases have been summarized previously (Fraser and Evan 1996; $\mathrm{N}$ ichol son 1996; N icholson and Thornberry 1997; Salvesen and Dixit 1997; Villa et al. 1997; Cryns and Yuan 1998), the present review will focus on recent insights into (1) the regulation of caspases (both positively and negatively) by other components of the cell death apparatus; and 2) the mechanisms by which caspase activation leads to the demise of the cell.

\section{A conserved cell death apparatus that regulates CED-3/ caspase activity}

Genetic studies of developmental PCD in C. el egans

${ }^{3}$ Corresponding author.

E-MAIL jyuan@warren.med.harvard.edu; FAX (617) 432-4177. have identified two genes (ced-3 and ced-4) that are each required for the execution of cell death and one (ced-9) that inhibits cell death (Hengartner et al. 1992; Y uan and Horvitz 1992; Yuan et al. 1993). Mutational analyses of these genes in $C$. el egans have defined a sequential cell death pathway. Inactivating mutations of ced-9 result in inappropriate cell deaths, but only if both ced-3 and ced-4 are functional (Hengartner et al. 1992). Targeted overexpression of either ced-4 or ced-3 induces cell death, these cell deaths are inhibited by ced-9. In transgenic worms, maximal cell death induced by ced-4 overexpression requires ced-3, whereas ced-3-mediated cell death is independent of ced-4. Moreover, the ability of ced-9 to inhibit ced-3-induced killing requires a functional ced-4 gene (Shaham and Horvitz 1996). Taken together, these findings suggest that ced-4 is genetically and functionally sandwiched between the upstream death antagonist ced-9 and the downstream death me diator ced-3. Accordingly, CED-9's antiapoptotic actions are likely mediated by direct inhibition of CED-4 (Shaham and Horvitz 1996).

Remarkably, all three of these $C$. elegans cell death genes have mammalian counterparts that are likely to play similar, al beit more complex, roles in mammalian cell death. CED-9 is homologous to $\mathrm{BCl}-2$, a resident of the mitochondrial outer membrane and the endoplasmic reticulum (ER)/perinuclear membrane whose dysregulated expression in several human mal ignancies protects against apoptotic cell death (Vaux et al. 1988; Krajewski et al. 1993; Hengartner and Horvitz 1994; Reed 1995). In contrast, CED-3 has sequence similarity to interleukin$1 \beta$-converting enzyme (ICE), the first mammalian member of the caspase family of cysteine proteases that are essential effectors of cell death and inflammation (Yuan et al. 1993). Final ly, a candidate mammalian homolog of CED-4, A paf-1 (apoptotic protease-activating factor-1), was identified recently by virtue of its ability to activate caspase-3 (Zou et al. 1997). The overall similarities between the nematode and mammalian cell death programs are striking. To begin, $\mathrm{Bcl}-2$ (and its antiapoptotic family members) protects cells from apoptosis by acting upstream of caspases to prevent their activation (Armstrong et al . 1996; Chinnaiyan et al. 1996b; Shimizu et al. 1996), just as CED-9 is a negative upstream regulator of CED-3. Moreover, recent evidence suggests that both CED-9 and BCl- $\mathrm{X}_{\mathrm{L}}$ (an antiapoptotic Bcl-2 family member) can antagonize cell death by acting downstream of 
CED-3 and some caspases, respectively (Boise and Thompson 1997; Xue and Horvitz 1997; Medema et al. 1998; Srinivasan et al. 1998). Similarly, A paf-1 exerts its proapoptotic action by facilitating the activation of its downstream target caspase-3, just as CED-4 promotes CED-3 processing and killing (see below). Furthermore, ectopic expression of ced-4 (in some systems) or ced-3 can induce apoptosis in mammalian cells that can be overcome by $\mathrm{Bcl}-2$ or caspase inhibitors (Miura et al. 1993; Chinnai yan et al. 1997b). Finally, human Bcl-2 can inhibit developmental PCD in C. elegans (Vaux et al. 1992), again highlighting the functional similarity of the worm and human cell death machinery. Nevertheless, the presence of multiple mammalian CED-9 (the $\mathrm{BCl}-2$ family) and CED-3 equivalents (the caspase family) with potentially redundant and/or antagonistic actions in apoptosis suggest, not surprisingly, that death has become a more complicated business during the course of evolution.

Recently, a series of landmark biochemical studies has provided us with a more detailed understanding of the molecular interactions of the various components of the cell death apparatus (for review, see Golstein 1997a; Hengartner 1997; Vaux 1997). Using yeast-two hybrid analyses or ectopic expression in mammalian cells, several groups have demonstrated that CED-4 can bind to CED-9 (and human $\mathrm{BCl}-\mathrm{X}_{\mathrm{L}}$ ) , CED-3 (and related human caspases-1 and 8), or both simultaneously (Chinnaiyan et al. 1997b; Irmler et al. 1997a; Spector et al. 1997; Wu et al. 1997). Indeed, an analogous mammalian "apoptosome" consisting of A paf- $1, \mathrm{BCl}-\mathrm{x}_{\mathrm{L}}$, and pro-caspase-9 has recently been reported (Pan et al. 1998). These interactions are functionally important for cell death signaling. For instance, CED-9 or human $\mathrm{BCl}-\mathrm{X}_{\mathrm{L}}$ mutants that are defective in their ability to inhibit cell death do not bind to CED-4 or A paf-1 (Chinnaiyan et al. 1997b; Spector et al. 1997; Wu et al. 1997; Pan et al. 1998). In addition, CED-4 binding to CED-3 is mediated by a conserved amino-terminal protein interaction module, the socalled caspase-recruitment domain (CARD) that is al so present in Apaf-1 and several caspases (Hofmann et al. 1997; Irmler et al. 1997a; Zou et al . 1997). CED-4 binding to CED-3 via this domain in the presence of ATP (and potentially other cellular factors) promotes CED-3's autoproteolytic activation and its ability to induce apoptosis (Chinnaiyan et al . 1997a; Seshagiri and Miller 1997b). Importantly, CED-9 blocks CED-4's ability to activate the CED-3 killer protease, thereby preventing cell death (Seshagiri and Miller 1997b). CED-9 may also act downstream of CED-3 as a pseudosubstrate inhibitor of this protease (Xue and Horvitz 1997). The nematode cell death apparatus, then, is elegantly parsimonious: Death is executed by a single protease (CED-3) whose acti vity is regulated by one activator (CED-4) and one inhibitor (CED-9). Viewed in this context, the cell death apparatus or "apostat" is a molecular "proteostat" that carefully integrates life and death signals into a proteolytic readout. In the remainder of this review, we will see that this prototypical death apparatus has been expanded and diversified in mammals to accommodate multiple pro- apoptotic proteases (the caspases) with multiple distinct routes of activation and inhibition, and multiple proteolytic targets.

\section{Caspases: natural bom killers}

With the cloning of ced-3 came the observation that it encoded a protease homologous to the mammalian ICE, a novel cysteine protease with aspartate specificity required for proteolytic conversion of pro-interleukin-1 $\beta$ into its mature form (Cerretti et al. 1992; Thornberry et al. 1992; Y uan et al. 1993). T ogether with the concurrent finding that apoptosis could be induced in mammalian cells by transient expression of ICE or ced-3 (Miura et al. 1993), these studies provided the first inkling that a conserved family of proteases might be a critical component of the cell death machinery. At the present time, at least 10 additional mammalian homologs of ced-3 have been published. Given the considerable confusion generated by the rapid growth of this family, the trivial names of these cysteine proteases with aspartate specificity (caspases) have been replaced with a uniform nomenclature: caspases-1 through -11 (Alnemri et al. 1996; Wang et al. 1998).

In addition to their sequence similarity to CED-3, the members of the caspase family of proteases have several unifying characteristics. As their name indicates, caspases are cysteine proteases, each containing a conserved QACXG pentapeptide surrounding the active site cysteine residue. Several other active site residues that participate directly in catalysis are strictly conserved across the family (for a detailed review of these and other structural/enzymatic features of these enzymes, see N icholson 1996; N icholson and Thornberry 1997; Cryns and Yuan 1998). Caspases are constitutively and ubiquitously expressed as catalytically inactive proenzymes composed of a variable-length amino-terminal prodomain, a large subunit, and a small subunit. Caspase activation requires proteolytic processing of the proenzyme at specific aspartate residues separating these three domains, thereby resulting in the removal of the prodomain and the formation of a heterodimer containing one large and one small subunit. Crystallographic analyses have demonstrated that the active caspase is a tetramer composed of two such heterodimers (Walker et al. 1994; Wilson et al . 1994; Rotonda et al . 1996). Although absent from the active enzyme, the amino-terminal prodomain plays a critical role in caspase activation by mediating the interaction of caspases with the activating apparatus (detailed subsequently). True to their family name, these proteases are "aspases": they cleave substrates (including pro-caspases) carboxy-terminal to an aspartate residue (the P1 site). This distinctive substrate specificity, coupl ed with their requi site proteolytic activation at Asp sites, immediately suggested that caspases might be responsible for their own activation (autoproteolysis) and/ or activation of other caspases. Reminiscent of the complement system in host defense, the caspases are arranged in a proteolytic cascade that serves to transmit and amplify death signals. 
Despite their uniform requirement for an Asp residues at the substrate P1 site, individual caspases differ in thei $r$ substrate specificities. These differences are dictated by the amino acids immediately amino-terminal to the substrate P1 site, especially the P4 site (four amino acids amino-terminal to the cleavage site). Recently, the substrate specificities of the caspases were delineated using a positional scanning substrate combinatorial library or synthetic peptides (Talanian et al. 1997; Thornberry et al. 1997). Based on their substrate preferences, three caspases subgroups were identified. The first subgroup (caspases-1, -4, and -5 ) prefer bulky hydrophobic residues in the P4 site and have the optimal substrate cleavage sequence WEXD. The second subgroup (caspases-2, -3 , -7, and CED-3) favor an Asp in P4 and preferentially cleave targets carboxy-terminal to a DEXD motif. The third subgroup (caspases-6, -8, and -9) are less discriminating in their P4 preferences; their optimal substrate cleavage sequence is (L/V)EXD. These findings are consistent with the X-ray crystallographic structures of caspases- 1 and 3 that are remarkably similar except in their respective binding pockets for the P4 substrate residues. This pocket in caspase-1 is quite large, and therefore capable of binding bulky hydrophobic residues, while the corresponding, much smaller pocket in caspase-3 is ideally suited for an Asp residue (Walker et al. 1994; Wilson et al. 1994; Rotonda et al. 1996). Importantly, the predicted caspase specificities correspond closely with the cleavage sites in the known intracellular caspase targets (Thornberry et al. 1997). For instance, caspase-1 cleaves pro-interleukin-1 $\beta$ at two sites (FEAD and YVHD) (Cerretti et al. 1992; Thornberry et al. 1992). Caspase 3 proteolyzes a number of structural and signaling proteins at DXXD sequences during the induction of apoptosis, including the DNA repair enzyme PARP (DEVD) (Lazebnik et al. 1994), the inhibitor of the caspase-activated DN Ase (DEPD and DAVD) (Sakahira et al. 1998, and the cytoskel etal protein gel solin (DQTD) (Kothakota et al. 1997). Finally, caspase-6 cleaves Iamin A (VEID), a key structural component of the nuclear envelope, during apoptosis (Takahashi et al. 1996).

In addition to their divergent substrate specificities, caspases differ in the length and sequence of their aminoterminal prodomains. CED-3 and caspases- $1,-2,-4,-5,-8$, -9 , and -10 all have long prodomains, whereas caspases-3, $-6,-7$, and -11 have short prodomains. Two distinct protein-protein interaction modules have been identified in the long prodomains. The first has been called the death effector domain (DED), two copies of which are present in both caspases-8 and -10 (Boldin et al . 1996; FernandesAlnemri et al. 1996; M uzi o et al . 1996; Vincenz and Dixit 1997). As will be discussed in detail below, this domain targets caspases-8 and -10 to ligand-activated death receptors (e.g., Fas/APO-1/CD95, TNFR1, and DR3) via specific protein interactions with a DED module in the adaptor protein FADD/M ORT 1 (Boldin et al. 1995; Chinnaiyan et al . 1995). In contrast, the prodomains of CED-3 and caspases-1, -2, -4, and -9 all contain a caspase recruitment domain (CARD) al so found in CED-4 (and its mammalian homolog Apaf-1) and the death adaptor protein
RAIDD/CRADD (Ahmad et al. 1997; Duan and Dixit 1997; Hofmann et al. 1997; Zou et al. 1997). As we shall see, this domain mediates the interaction between A paf- 1 and pro-caspase-9, a necessary event leading to caspase 9 and subsequently caspase 3 activation ( $P$. Li et al. 1997). Similarly, caspase-2 can be delivered to activated death receptors via CARD domain interactions in its prodomain and in the death adaptor RAIDD/CRADD (A hmad et al. 1997; Duan and Dixit 1997). In this sense, the prodomains provide the critical link between the death stimulus and caspase activation: they either target a caspase to the activating death receptor at the cell membrane or provide the molecular foundation for assembly of the caspase activating apparatus in the cytoplasm (Fig. 1).

The observation that some pro-caspases $(2,8$, and 10$)$ are recruited directly to membrane receptors via their prodomains provided important experimental evidence for the proteolytic cascade theory of caspase signaling; these receptor-interacting caspases are at the very top of this cascade. Additional support for this theory came from the finding that caspases with distinct proteolytic profiles were activated at different times during Fas-induced apoptosis: Transi ent activation of a caspase-1-like protease was required for subsequent activation of a caspase-3-like protease (Enari et al. 1995). From a functional standpoint, then, caspases can be loosely divided into upstream "instigators," which incite the proteol ytic cascade and downstream "terminators," which kill the cell by cleaving key intracellular death targets (Bol din et al. 1996; Muzio et al. 1996, 1997; Orth et al. 1996b; Srinivasula et al. 1996; Talanian et al. 1997; Thornberry et al. 1997; see al so Fig. 1). The instigators include the long prodomain, DED-containing caspases-8 and -10, and the CARD-containing caspase-9. Of note, the substrate cleavage preferences of these instigators correspond closely to the sites of proteolytic activation in several effector caspases, suggesting that these upstream proteases may directly activate their downstream counterparts, as has been demonstrated in vitro. In contrast, the terminators include the short prodomain caspases-3 and -7 whose predilection for proteolyzing targets at DXXD motifs matches the cleavage sites in the vast majority of known apoptotic substrates (Boldin et al. 1996; M uzio et al. 1996, 1997; Orth et al. 1996b; Srinivasula et al. 1996; Talanian et al . 1997; Thornberry et al. 1997). In addition, the short prodomain caspase 6 acts as a terminator by cleaving a partly distinct subset of cellular proteins, such as the nuclear lamins and the structurally related keratin 18, at VEXD sites (Rao et al. 1996; Takahashi et al. 1996; Caulín et al. 1997). Like CED-3, caspase-2 is a CARDcontaining caspase with a DXXD substrate cleavage preference that may function as both an upstream signal activator and downstream killer. Finally, caspase-1 (and related caspases $-4,-5$, and -11 ) plays an essential role in the generation of the inflammatory response and in pathological apoptotic cell deaths (e.g., ischemic injury), perhaps acting as both an initiator and effector (Kuida et al. 1995; Li et al. 1995; Miura et al. 1995; Enari et al. 1996; Shi et al. 1996; Hara et al. 1997; Wang et al. 1998). 
Figure 1. A poptotic cell death: a working blueprint. Caspases can be activated by one of two potentially interacting and reversible pathways: a mitochondrial (left) and a death receptor (right) route. By unclear mechanisms, apoptotic stimuli such as DNA damaging agents trigger the mitochondrial release of cytochrome $\mathrm{c}$ into the cytosol, an event that is antagonized by $\mathrm{BCl}-2$ and its antiapoptotic relative $\mathrm{BCl}-\mathrm{x}_{\mathrm{L}}$. In the cytoplasm, cytochrome $c$ binds to the CED-4 homolog A paf-1, which interacts with both death effectors (pro-caspase-9) and death antagonists $\left(B C l-X_{L}\right)$ to form the apoptosome (the interaction between $\mathrm{BCl}-\mathrm{x}_{\mathrm{L}}$ and A paf- 1 is not shown). Binding of cytochrome $c$ and (d)ATP to Apaf-1 somehow promotes its ability to catalyze the proteolytic activation of pro-caspase-9, whereas $\mathrm{BCl}-\mathrm{x}_{\mathrm{L}}$ presumably inhibits this function. Active caspase-9, in turn, proteolytically activates the downstream caspase terminators such as caspase- 3 that kill cells by cleaving key intracellular proteins (see Table 1). In contrast, binding of death ligands such as TNF $\alpha$, Fas, and TRAIL to their respective death receptors [each containing a cytoplasmic death domain (DD)] leads to the recruitment of a variety of DD-bearing adaptor proteins such as FADD. FADD in turn recruits the most upstream pro-caspases (procaspases- 8 and -10) to the receptor complex via a distinct protein interaction module (the DED domain), an event that leads to the proteolytic activation of these caspase instigators and initiation of a proteolytic cascade that ultimately results (if unchecked) in the demise of the cell as above. In addition, these activated upstream caspases may act on the mitochondria (directly or indirectly) to facilitate cytochrome c release, thereby further amplifying the apoptotic signal. Death-receptor mediated apoptosis can be inhibited by preventing pro-caspase recruitment/activation (the DED-containing protein FLIP) or by prematurely

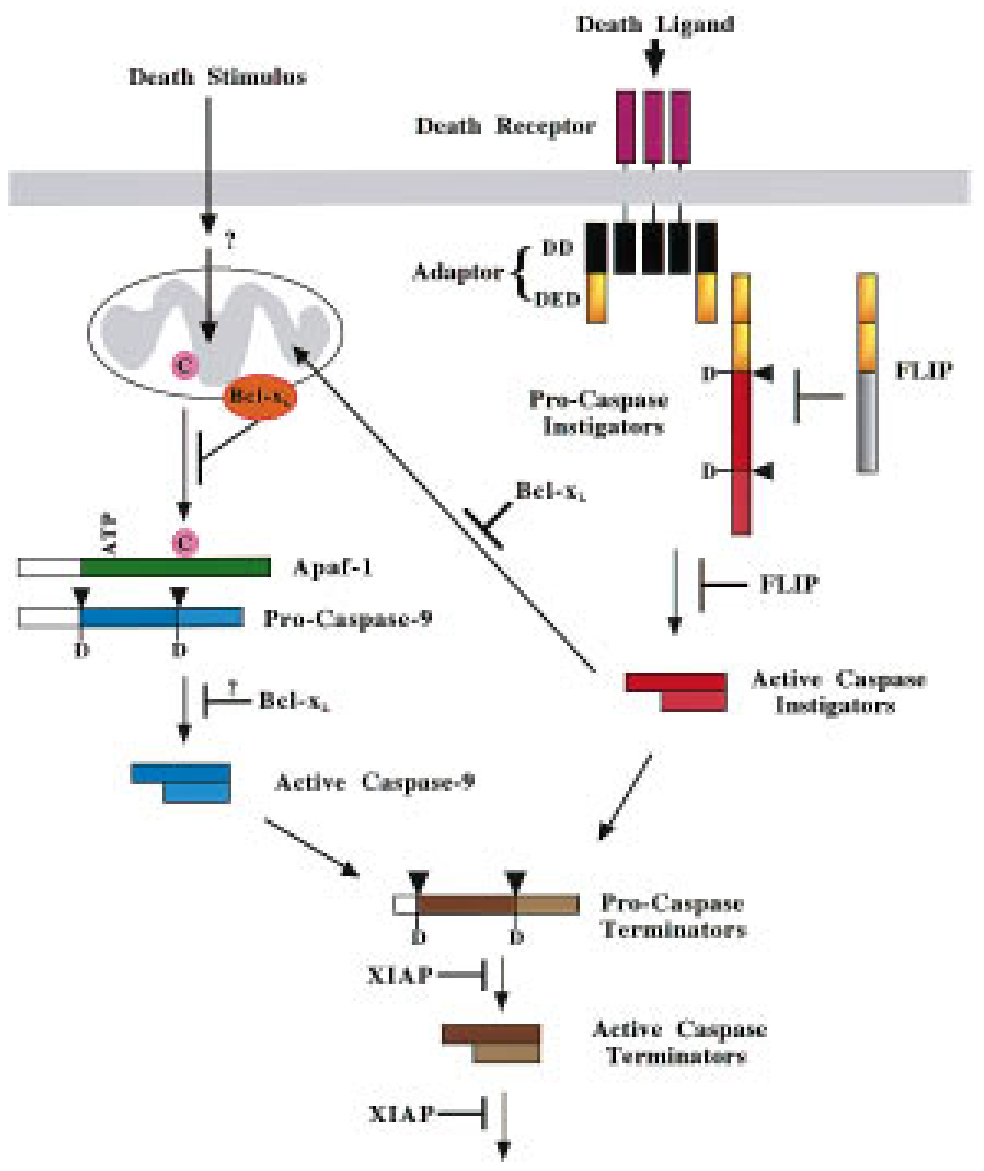

Death by Cleavage of Key Intracellular Targets hal ting the caspase proteolytic cascade after its initiation $\left(\mathrm{BCl}-\mathrm{X}_{\mathrm{L}}\right)$. XIAP, a mammalian homolog of the baculoviral IAPs (inhibitor of apoptosis) is an active site-directed inhibitor of the downstream caspases-3 and -7 and represents the final protective barrier against unwarranted cell death induced by either pathway.

Evidence for its role in the latter capacity comes from the observation that mature IL-1 $\beta$, the specific product of caspase-1's proteolytic actions on its precursor cytokine, directly promotes cell death induced by some stimuli (Friedlander et al. 1996). Clearly, this division of caspases into instigators and terminators is likely to be overly simplistic: Upstream caspases may contribute to the structural disassembly of the cell and downstream caspases may al so proteolytically activate other caspases.

What, then, is the evidence that caspases are essential effectors of apoptotic cell death (for review, see Cryns and Yuan 1998)? As noted, forced expression of these proteases (and others) causes apoptosis (Miura et al. 1993; Fernandes-Alnemri et al. 1994; Kumar et al. 1994; Wang et al. 1994). In addition, several pro-caspases (1, 2, $3,6,7$, and 8 ) are rapidly proteolytically activated during cell death induced by a wide range of apoptotic stimuli (Boudreau et al. 1995; Armstrong et al. 1996; Duan et al. 1996; Orth et al. 1996a; Shi et al. 1996; Faleiro et al. 1997; H. Li et al. 1997; M acFarlane et al. 1997b; M edema et al. 1998; Srinivasan 1998). Furthermore, many of the proteins that are sel ectively cl eaved during cell death are proteolyzed at Asp residues by caspases. M ore di rect evidence is the observation that specific inhibitors of caspases (peptides, viral gene products, dominant-negative caspases, and anti-sense constructs) can block a wide variety of apoptotic cell deaths in vitro and in vivo, including cell death mediated by death receptors (see below), growth factor withdrawal, radiation and other DN A damaging agents, detachment from the extracellular matrix, and developmental cues (in diverse organisms) (Gagliardini et al. 1994; Boudreau et al . 1995; Bump et al. 1995; Enari et al. 1995; Los et al. 1995; Tewari and Dixit 1995; Xue and Horvitz 1995; Bertin et al . 1996). For instance, potent, specific peptide inhibitors have been modeled after the substrate recognition sequences of a variety of caspases (e.g., DEVD for caspase-3 and YVAD for caspase-1) (Thornberry et al. 1992; $\mathrm{Nicholson}$ et al. 1995). In addition to confirming the role of caspases collectively in the execution of apoptosis, the tetrapeptide inhibitors (particularly the reversi ble al dehydes) provide some sense of the relative contribution of particular 
caspases (e.g., caspase-3-like vs. caspase-1-like proteases) by preferentially inhibiting one or more caspases. However, given the lack of absolute specificity of any one of these peptie inhibitos for a particular caspase, such studies must be interpreted with caution. Clearly, the most definitive support for their essential role in programmed cell death in vivo comes from their targeted deletion; this approach al so enables one to selectively eval uate the specific contribution of an individual caspase to the execution of apoptosis in vivo. Mice deficient in caspase-1 or caspase-11 undergo normal development but have partial, tissue-specific resistance to Fas- and granzyme-B mediated apoptosis (Kuida et al. 1995; Li et al. 1995; Shi et al. 1996; Wang et al. 1998; S. Wang and J. Y uan, unpubl.). In contrast, mice deficient in caspase-3 are characterized by central nervous system (CNS) hypercelluIarity (focal areas within grossly smaller brains) and perinatal death; these features may reflect, in part, inadequate cell death in the CNS during development (Kuida et al. 1996). However, it is unlikely that the aberrant brain development in these mice is simply the result of defective apoptosis: neuronal overexpression of $\mathrm{BCl}-2$ in transgenic mice also suppresses PCD in the developing brain but results in a profoundly different phenotype, that is, normally viable mice with grossly enlarged brains (Martinou et al. 1994). Somewhat suprisingly, homozygous deletion of caspase-2 in mice has both anti- and proapoptotic consequences in different tissues (Bergeron et al. 1998). Ovarian germ cells from caspase-2-deficient mice are resistant to developmental and doxorubicin-induced cell death, whereas specific neuronal populations demonstrate accelerated apoptosis during development or growth factor withdrawal. These paradoxical manifestations may reflect tissue-specific differences in the expression of the pro- and antiapoptotic isoforms of caspase-2 generated by al ternative spl icing (both of which are del eted in these animals): caspase$2_{L}$ is prominently expressed in ovaries and encodes a functional protease, whereas caspase- $2_{\mathrm{S}}$ is most abundant in the brain and encodes a truncated, inactive protease that antagonizes cell death (Wang et al. 1994). Finally, functional disruption of the Drosophila caspase, DCP-1, results in multiple developmental defects (with sparing of the CNS), wide-spread melanotic tumors, and larval death (Song et al. 1997). Taken together, these findings indicate unequivocally that caspases are essential mediators of cell death. Moreover, the highly selective apoptotic defects observed in mammalian knockouts of individual caspase family members strongly suggest that a great deal of functional redundancy has been built into the death apparatus (a conclusion also supported by the partial ly overl apping substrate specificities of some caspases in vitro). Hence, elimination of one caspase can often be compensated for by other caspases with similar proteolytic profiles.

\section{Caspase activation: jump-starting the proteolytic engine}

Under normal conditions, caspases are present in the cy- tosol as inert proenzymes that pose no danger to the cell. For a cell to undergo apoptosis, caspases must be activated by proteolytic processing at Asp sites, an event that leads to a self-amplifying cascade of proteolysis among the caspases. For any enzymatic cascade, the critical issue is its mechanism of initiation. Specifically, if caspases activate other caspases, how does the first caspase get activated? As outlined in Figure 1, two potentially interacting, cascade-initiating pathways converge on the activation of the downstream effector caspases (terminators such as caspase-3) that act to kill the cell by cleaving death substrates. The first of these pathways (and seemingly the most primitive from an evolutionary perspective) is initiated in response to apoptotic stimuli such as DNA damaging agents that trigger the mitochondrial release of cytochrome $\mathrm{c}$ into the cytoplasm; once in the cytoplasm, cytochrome c interacts with other factors to form a caspase-3-activating complex. In the second pathway, caspase proenzymes are recruited to ligand-bound death receptors via homophilic interactions with adaptor proteins (e.g., FADD/ MORT 1), thereby leading to the proteolytic activation of these most upstream caspases and initiation of the cascade. These signaling routes may cross-communicate prior to their convergence. For instance, ligand binding to death receptors has been shown to stimulate mitochondrial cytochrome c release in most (but not all) studies (Chauhan et al. 1997; Vander Heiden et al. 1997; Duckett et al. 1998; Srinivasan et al. 1998). Mitochondrial cytochrome $\mathrm{c}$ rel ease induced by death receptor $\mathrm{li}$ gation may be executed by the upstream caspases themselves (Vander Heiden et al. 1997), whereas its efflux triggered by other apoptotic stimuli is likely to be a caspase-independent event (Kharbanda et al. 1997; Kluck et al. 1997a; Yang et al. 1997; Bossy-Wetzel et al. 1998) (see Fig. 1). Both of these caspase activating pathways have multiple barriers to prevent inappropriate cell death: Endogenous inhibitors block the initiation of the caspase cascade and/or interrupt its forward progression. In the remainder of this section we will analyze these pathways in detail.

The initially perplexing (and serendipitous) discovery that cytochrome c, a key component of the mitochondrial electron transport chain, is necessary for the induction of apoptosis in a cell-free system led several investigators to examine its role in apoptosis. Consistent with its pro-apoptotic role in vitro, cytochrome $\mathrm{c}$ is rapidly released from the mitochondrial intermembrane space into the cytoplasm during the induction of apoptosis by diverse stimuli. Importantly, cytochrome c's cytoplasmic rel ease (triggered by stimuli other than death receptor ligands) precedes caspase-3 activation and DN A fragmentation, and is in fact required for these activities. Cytosolic extracts that had been stripped of cytochrome c by immunodepleti on were unable to activate caspase-3 or induce DN A fragmentation; these activities could be restored by addition of holocytochrome c (complexed with heme) but not apocytochrome c (Liu et al. 1996; Yang et al. 1997). Bcl-2 and its antiapoptotic relative Bcl$\mathrm{X}_{\mathrm{L}}$ are located predominantly in the outer mitochondrial 
membrane; their proximity to cytochrome c suggested that they might regul ate the latter's rel ease during apoptosis. Indeed, overexpression of $\mathrm{Bcl}-2 / \mathrm{BCl}-\mathrm{x}_{\mathrm{L}}$ or addition of recombinant $\mathrm{BCl}-2$ to Xenopus egg extracts containing mitochondria prevented cytochrome c's exodus from the mitochondria that was triggered normally by apoptotic stimuli such as DNA damaging agents and staurosporine; caspase inhibitors (peptides or the baculovirus p35 gene) had no effect on this process (Kharbanda et al. 1997; Kluck et al. 1997a; Yang et al. 1997; Bossy-Wetzel et al. 1998). In these systems, Bcl-2 acts upstream of cytochrome $c$ release within the mitochondria. In contrast, the pro-apoptotic Bcl-2 family member Bax stimulates mitochondrial cytochrome c release (Deveraux et al. 1997; Rossé et al. 1998). The molecular mechanisms by which Bax stimulates and $\mathrm{Bcl}-2 / \mathrm{BCl}-\mathrm{x}_{\mathrm{L}}$ inhibits cytochrome c's mitochondrial egress is unclear but may be related to their ability to form membrane pores with distinct ion-conducting properties; $\mathrm{BCl}-2$ also inhibits Bax's ability to form lipid channels (Antonsson et al. 1997; Minn et al. 1997; Schendel et al. 1997). Moreover, $\mathrm{Bcl}-\mathrm{x}_{\mathrm{L}}$ can bind to cytochrome $\mathrm{c}$ and may thereby act to sequester it in the mitochondria (Kharbanda et al. 1997). Furthermore, $\mathrm{Bcl}-\mathrm{x}_{\mathrm{L}}$ inhibits the osmotic swelling of mitochondria and subsequent outer membrane disruption induced by apoptotic stimuli that may directly lead to the cytosolic efflux of cytochrome c (Vander Heiden et al. 1997).

To further complicate matters, recent evidence indicates that $\mathrm{BCl}-2$ and $\mathrm{BCl}-\mathrm{x}_{\mathrm{L}}$ may al so act downstream of cytochrome $c$ to prevent caspase activation under certain circumstances. For instance, overexpression of $\mathrm{BCl}-\mathrm{x}_{\mathrm{L}}$ or $\mathrm{BCl}-2$ inhibits apoptosis induced by direct microinjection of cytochrome c into cells (F. Li et al. 1997; Zhivotovsky et al. 1998). Similarly, overexpression of Bcl-2 prevents Bax-induced caspase activation and cell death even though it has no effect on Bax-induced mitochondrial cytochrome c release (Rossé et al . 1998). How Bcl-2/Bcl$\mathrm{X}_{\mathrm{L}}$ might act downstream of cytochrome $\mathrm{c}$ release to prevent caspase activation is also unresolved. By virtue of its ability to bind to cytochrome c, extra-mitochondrial $\mathrm{BCl}-\mathrm{x}_{\mathrm{L}}$ (i.e., perinuclear and ER membrane stores) may remove cytochrome $c$ from the freely available cytoplasmic pool and thereby prevent caspase activation. In addition, $\mathrm{BCl}-2 / \mathrm{BCl}-\mathrm{x}_{\mathrm{L}}$ may negatively regulate the other components of the caspase-3 activating apparatus (see the following). One final speculative possibility is that $\mathrm{BCl}-2 / \mathrm{BCl}-\mathrm{x}_{\mathrm{L}}$ might function as a direct inhibitor of one or more caspases. Indeed, the $C$. elegans CED-9 protein can be cleaved by CED-3 at two sites near its amino terminus and the presence of at least one of these sites is important for complete protection by CED-9 against cell death, suggesting that CED-9 may act as a pseudosubstrate inhibitor of CED-3 (Xue and Horvitz 1997). However, although $\mathrm{BCl}-2$ and $\mathrm{BCl}-\mathrm{x}_{\mathrm{L}}$ are cleaved by caspases during apoptosis induced by some stimuli, there is no experimental evidence that they function as active sitedi rected inhibitors of caspases (Cheng et al. 1997; Clem et al. 1998; Grandgirard et al. 1998). Regardless of its precise molecular mechanism, $\mathrm{Bcl}-2 / \mathrm{BCl}-\mathrm{x}_{\mathrm{L}}{ }^{\prime} \mathrm{s}$ antiapop- totic actions likely reflects its combined ability to prevent cytochrome $c$ release in some situations and to inhibit cytochrome c-induced caspase activation in others, a true testament of its versatility.

What, then, is the $\mathrm{Bcl}-2$ antagonized signal that triggers the mitochondrial release of cytochrome $c$ during the induction of apoptotic cell death? One intriguing candidate is the reduction in mitochondrial transmembrane potential (depolarization), a relatively early, $\mathrm{Bcl}-2$ inhi bi table event in apoptosis that reflects the opening of mitochondrial megachannels (Zamzami et al. 1995, 1996a,b). However, in several different apoptotic systems (e.g., cell death induced by DN A damaging agents and staurosporine), cytochrome c release preceded mitochondrial membrane potential changes by many hours; in Xenopus egg extracts, cytochrome c rel ease occurred during apoptosis even though mitochondrial membrane depolarization was never observed (Yang et al. 1997; Kluck et al. 1997a; Kharbanda et al. 1997; Bossy-Wetzel et al. 1998). M oreover, during apoptosis induced by DN A damage or protein kinase inhibition, disruption of the mitochondrial membrane potential, but not cytochrome c release, is prevented by caspase inhibitors (Susin et al. 1997; Kluck et al. 1997a; Kharbanda et al. 1997; BossyWetzel et al. 1998). Under these circumstances, these two processes can be dissociated unambiguously: Loss of the mitochondrial membrane potential is a consequence, not an antecedent of, caspase activation. Caspase-1 can induce membrane depolarization in isolated mitochondria, a process associated with the rel ease of a pro-apoptotic, yet-to-be identified caspase (AIF) that may play an accessory role in apoptosis (Susin et al. 1997). N evertheless, the caspase-mediated disruption of the mitochondrial membrane potential might serve to amplify the death signal by facilitating the mitochondrial release of cytochrome $c$ during death receptor-mediated apoptosis (see Fig. 1, and below) and the later stages of PCD induced by DN A damaging agents (Hengartner 1998). M ore recent studies suggest that many apoptotic (and necrotic) stimuli induce progressive mitochondrial swelling that ultimately ruptures the outer mitochondrial membrane, thereby allowing cytochrome c to leak out of the mitochondria into the cytosol (Vander Heiden et al. 1997). Importantly, these newly recognized apoptotic events in the mitochondria (swelling and subsequent membrane rupture) are prevented by $\mathrm{BCl}-\mathrm{x}_{\mathrm{L}}$ and precede mitochondrial membrane depolarization; hence, they may represent the primary trigger for cytochrome $c$ rel ease during cell death.

Upon its release into the cytoplasm during the initiation of apoptosis, cytochrome c forms a caspase-3 activating complex, the apoptosome. The activating components of this compl ex have been meticulousl y teased out in several elegant biochemical studies by Wang and coworkers (Liu et al. 1996; P. Li et al. 1997; Zou et al. 1997). These investigators observed that addition of dATP to a cell-free extract prepared from nonapoptotic cells led to caspase 3 activation and DNA fragmentation when exogenous nuclei were added. This caspase-3 activation could be completely reconstituted by four components: 
(d)ATP, cytochrome c, the mammalian CED-4 homolog A paf-1, and caspase-9. Omission or immunodepletion of any of these factors prevents caspase 3 activation. A paf- 1 has three functional domains: an amino-terminal CARD with homology to CED-3 and several caspases; a middle CED-4-like domain that includes a conserved nucl eotide binding module (P-loop); and a carboxy-terminal region with many WD repeats (a presumptive protein-protein interaction motif). Apaf-1 binds to caspase-9 via their respective amino-terminal CARD domains, an interaction that requires dATP and cytochrome $c$. Binding of dATP and cytochrome c to A paf-1 likely al ter the latter's conformation and render its CARD domain more readily availabl e to caspase-9. dATP (or higher concentrations of ATP) may interact with the nucleotide binding domain in A paf-1 that is conserved in CED-4; mutations of this regi on in CED-4 impair its ability to activate CED-3 and induce apoptosis (Chinnai yan et al. 1997a; Seshagi ri and Miller 1997b). Once bound to caspase-9, A paf-1 triggers caspase-9's proteolytic self-activation; caspase 9 subsequently proteolyzes and activates caspase-3. Consistent with caspase-9's role in caspase 3 activation and subsequent apoptotic events, overexpression of a catalytically inactive caspase- 9 mutant blocks Apaf-1's ability to activate caspase-3 and induce cell death (P. Li et al. 1997). The apoptosome, then, is a caspase- 3 activating apparatus whose assembly is dependent on the antecedent release of cytochrome $c$ from mitochondria. Recently, $\mathrm{BCl}$ $X_{L}$ has been shown to bind specifically to the CED-4-like domain of A paf-1; this antiapoptotic Bcl-2 family member is displaced from the apoptosome by its proapoptotic relatives Bax and Bak (Pan et al. 1998). Although the functional significance of this binding (and its precise intracellular locale) has yet to be determined, one could certainly envision an "evolutionarily correct" scenario whereby $\mathrm{BCl}-\mathrm{x}_{\mathrm{L}}$ would interfere with Apaf-1's ability to activate pro-caspase-9; perhaps, this is the basis for $\mathrm{BCl}$ 2/BCl- $x_{L}{ }^{\prime} S$ inhibition of caspase activation downstream of cytochrome $c$ release. Another unresolved issue is whether each effector caspase has its own apoptosome; alternatively, caspase-3 might activate these other caspases. Interestingly, microinjection of cytochrome c does not lead to caspase activation and cell death in mammalian cells devoid of caspase-3 (F. Li et al. 1997), suggesting an inherent specificity of the cytochrome $c$ pathway. Consistent with these observations is the finding that Apaf-1 appears to be selective about its caspase binding partners: it does not interact with pro-caspases 1, 2, 3, or 8 (Pan et al. 1998). Finally, how does the interaction of A paf-1 with pro-caspase-9 (in the presence of dATP and cytochrome c) catalyze the latter's autoproteolytic activation? One possibility is that this interaction triggers a conformational change in pro-caspase-9 that uncovers a dormant proteolytic capability and/or renders the critical Asp residues more accessible to cleavage, leading to its autoactivation.

The second caspase activating route begins outsi de the cell with ligand binding to a so-called death receptor. This growing subset of the tumor necrosis factor (TNF)/ nerve growth factor (NGF) receptor family all share a conserved cytoplasmic protein-protein interaction module termed the death domain (DD) because of its indispensable role in apoptotic signaling (for review, see $\mathrm{Na}$ gata 1997). Mammalian death receptors include Fas/ APO-1/CD95, TNFR1, DR3/WSL-1/Apo-3/TRAMP, and the TRAIL receptors DR4/TRAIL-R1 and DR5/ TRAIL-R2/Trick2/KILLER (for review, see Golstein 1997b). Activation of these receptors by binding of their respective ligands leads to the recruitment of one or more mutually interacting, DD-containing adaptor proteins: FADD/M ORT1 (Boldin et al. 1995; Chinnaiyan et al. 1995), TRADD (Hsu et al. 1995), RIP (Stanger et al. 1995), RAIDD/CRADD (Duan and Dixit 1997; Ahmad et al. 1997), and MADD (Schievella et al. 1997). FADD/ MORT 1 provides the direct link between these activated death receptor complexes and the caspase proteolytic cascade, although its role in TRAIL-induced apoptosis via DR4 and DR5 has been supported by some studies (Chaudhary et al. 1997; Schnei der et al . 1997b; Wajant et al. 1997; Wal czak et al. 1997) but not others ( $M$ arsters et al. 1996; Pan et al. 1997a,b; Sheridan et al. 1997). FADD / MORT1 is recruited via its carboxy-terminal DD either di rectly (Fas and possibly DR4 and DR5) or indi rectly via TRADD (TNFR1 and DR3) to the corresponding cytoplasmic DD in these receptors (Chinnaiyan et al. 1995, 1996a,b; Boldin et al. 1995; Hsu et al. 1996; Kitson et al. 1996; Chaudhary et al . 1997). Once incorporated into the ligand bound-death receptor complex (the death-inducing signaling complex or DISC), FADD/MORT1 relies on a distinct protein-protein interaction module in its amino terminus, the death effector domain (DED), to engage the upstream caspases and induce apoptosis. Specifically, FADD/M ORT1 recruits pro-caspase-8 and/or pro-caspase-10 to the DISC via their respective DEDs (one in FADD/MORT1 and two in the amino-terminal prodomain of these caspases); the various death receptors may differ somewhat in their relative abilities to recruit pro-caspase-8 versus pro-caspase-10 (Boldin et al. 1996; Chinnaiyan et al. 1996a; Fernandes-A Inemri et al. 1996; Muzio et al. 1996; Srinivasula et al. 1996; Pan et al. 1997a; Vincenz and Dixit 1997). Delivery of these DEDbearing caspase proenzymes to the DISC leads to their proteolytic activation: The large/small subunit heterodimer (which oligomerizes to form the active tetramer) is rel eased into the cytopl asm to incite the caspase cascade while the prodomain remains transiently tethered to the DISC (Boldin et al. 1996; Fernandes-Alnemri et al . 1996; Muzio et al. 1996). Disruption of this interaction between FADD/M ORT 1 and these proximal caspases by overexpression of a dominant negative FADD/M ORT 1 (lacking its DED and therefore unable to recruit caspase proenzymes to the DISC) prevents apoptosis mediated by death receptors (again, there are conflicting data with regard to TRAIL-induced cell death) (Chinnaiyan et al. 1996a,c; H su et al. 1996; M arsters et al. 1996; Chaudhary et al. 1997; Pan et al. 1997a,b; Schneider et al. 1997b; Wajant et al. 1997; Walczak et al. 1997). In an entirely anal ogous manner, the DD-containing RAIDD/CRADD is targeted to the death domain of RIP in the ligand activated TNFR1-TRADD-RIP complex. RAIDD/ 
CRADD then recruits pro-caspase 2 to the DISC via their respective CARD domains, an event that may lead to caspase-2 proteolytic activation (Ahmad et al. 1997; Duan and Dixit 1997). However, this interaction may not be essential for death signaling by TN F $\alpha$ : Embryonic fibroblasts derived from mice deficient in caspase-2 are no less sensitive to TNF $\alpha$-induced apoptosis than the corresponding fibroblasts from wild-type mice (Bergeron et al. 1998). Hence, the TN FR 1 signaling complex (and possibly others) can si mul taneously attract and facilitate the proteolytic processing of multiple caspases, some of which may be performing partly redundant functions. Finally, an intracellular caspase activating apparatus has been recently described: p28 Bap31 is an integral ER membrane protein that recruits pro-caspase-8, $\mathrm{BCl}-2 / \mathrm{BCl}-\mathrm{x}_{\mathrm{L}}$ and possibly Apaf-1 to form an ER-based apoptosome-like complex (N g et al. 1997; N g and Shore 1998).

How, then, does the adaptor-mediated recruitment of the pro-caspases to the DISC lead to their proteolytic activation? Perhaps, binding of these pro-caspases to their adaptors induces a conformational change that unmasks their proteolytic activity, as was postulated for Apaf-1-induced activation of pro-caspase-9. An alternative (but not mutually exclusive) hypothesis is that recruitment of pro-caspases possessing minimal, but discernible, proteolytic activity to the DISC leads to a critical concentration of proteases in the local microenvironment that facilitates their intermolecular interaction and subsequent activation ( $\mathrm{N}$ icholson and Thornberry 1997; Martin et al. 1998; Muzio et al. 1998). This hypothesis is supported by the observation that chemically induced dimerization of membrane-targeted procaspase-8 resulted in its proteolytic autoactivation and ability to induce apoptosis. In these experiments, dimerization of a pro-caspase-8 fusion protein containing multiple FK506 binding sites in its prodomain (and a myristoylation motif for membrane delivery) was triggered by the additi on of an FK506 dimer (M uzio et al . 1998). SimiIar results were obtained by transfecting cells with a chimeric caspase- 8 construct in which its prodomain had been replaced with an amino-terminal CD8 dimerization domain (M artin et al. 1998). Once activated, these DEDbearing instigator caspases proteolytically activate (directly and/or indirectly) the downstream terminator caspases (e.g., caspases-3 and -7) that are responsible for executing the cell by cleaving key intracellular proteins; caspase-9 may be an important intermediary in this process (Pan et al. 1998). M oreover, these insti gator caspases may also directly or indirectly promote the cytosolic efflux of cytochrome c from the mitochondria (see Fig. 1), thereby further amplifying the death signal. Experimental evidence in support of their ability to function in this capacity comes from the observation that caspase inhibitors can block mitochondrial cytochrome c release induced by Fas-ligation but not by staurosporine (Vander Heiden et al. 1997). Finally, these upstream caspases may themselves contribute di rectly to the structural dismantling of the cell.

Like the mitochondrial cytochrome c-dependent path- way, the DISC recruitment pathway of caspase activation is regulated negatively by endogenous inhibitors. An important clue to the existence of one such mammalian inhibitor of death receptor-induced caspase activation and apoptosis came with the discovery of a family of viral proteins that contain two DEDs (Bertin et al. 1997; $\mathrm{Hu}$ et al. 1997; Thome et al. 1997). These viral proteins disrupt the recruitment of pro-caspases-8 and -10 to the DISC by competing with these caspases for binding to the DED of FADD/MORT 1; viral subversion of this critical step in caspase activation prevents apoptosis of host cells, thereby enabling continued viral replication (for review, see Thompson 1995). Shortly thereafter, a homologous mammalian DED-containing protein was identified by several groups and variously named FLIP/ Casper/I-FLICE/FLAME-1/CASH/CLARP/MRIT (hereafter referred to as FLIP). FLIP is expressed in mammalian cells as two alternatively spliced messages. The FLIP $_{S}$ protein contains two amino-terminal DEDs and structurally resembles the viral DED proteins. FLIP contains a carboxy-terminal domain beyond these two DEDs and resembles caspases- 8 and -10 in its overall structure. In contrast to these caspases, however, FLIP is devoid of protease activity, presumably because it lacks several strictly conserved residues that are essential for caspase proteolysis, including the catalytic Cys residue (Irmler et al. 1997b; Goltsev et al. 1997). Although transient overexpression of FLIP $_{\mathrm{L}}$ has been reported to inhibit death receptor-mediated apoptosis in some situations (Gol tsev et al . 1997; Hu et al . 1997; Irmler et al. 1997b; Srinivasula et al. 1997) and to induce cell death in others (Irmler et al. 1997b; Goltsev et al. 1997; Inohara et al. 1997; Han et al. 1997), stable overexpres-

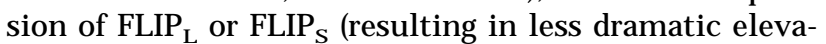
tions in protein levels) protected cells against death receptor-induced apoptosis (Irmler et al. 1997b). Further evidence that FLIP normally antagonizes rather than promotes apoptosis comes from the observation that FLIP is overexpressed in human metastatic melanomas and in $\mathrm{T}$ lymphocytes during the initial response to mitogen stimulation; these cells are resistant to killing by Fas ligation (Irmler et al. 1997b). Several studies, but not all, have demonstrated that FLIP (both isoforms) can bind to FADD/M ORT 1, caspase-8, and caspase-10 via DED-mediated homophilic interactions (Goltsev et al. 1997; Han et al. 1997; Inohara et al. 1997; Irmler et al. 1997b). Like their viral counterparts, both FLIP $_{\mathrm{L}}$ and FLIP $_{\mathrm{S}}$ displace caspases- 8 and -10 from the DISC by competing for binding to FADD/MORT1, thereby preventing the initiation of the caspase proteolytic cascade. In addition, FLIP may directly inhibit caspase- 8 by forming catalytically dead heterodimers or by functioning as a pseudosubstrate inhibitor (Irmler et al. 1997b). Consistent with its mechanism of action, FLIP does not inhibit apoptosis induced by stimuli that signal through pathways other than death receptors, such as staurosporine or UV-irradiation (Irmler et al. 1997b; Srinivasula et al. 1997).

Another mechanism for inhibiting death receptor-induced caspase activation is illustrated by the decoy receptors for TRAIL. In contrast to the death signal ing re 
ceptors for TRAIL, these decoy receptors either lack a cytoplasmic tail and consequently have no death domain (TRID/DCR1/TRAIL-R3) or contain a nonfunctional, truncated death domain (DcR2/TRAIL-R4) (Degli-Esposti et al. 1997; MacFarlane et al. 1997a; Marsters et al. 1997; Pan et al . 1997a; Schneider et al . 1997a; Sheridan et al. 1997). Overexpression of these decoy receptors specifically inhibits TRAIL-induced apoptosis, presumably by sequestering the TRAIL ligand away from its death signaling receptors DR4 and DR5 and preventing DISC formation. Indeed, the selective sensitivity of many tumor cell lines to TRAIL-induced apoptosis may reflect the loss of expression of these decoy receptors during tumor progression/initiation (Pan et al. 1997a; Sheridan et al. 1997). It remains to be seen whether this distinctive strategy to influence the susceptibility of a given cell to TRAIL-induced apoptosis has been deployed by other death-signaling pathways.

In addition, recent findings suggest that $\mathrm{BCl}-\mathrm{x}_{\mathrm{L}}$ may antagonize death receptor mediated-apoptosis by inhibiting a yet-to-be identified step downstream of caspase-8 activation (Boise et al. 1997; M artin et al. 1998; M edema et al. 1998). Overexpression of $\mathrm{BCl}-\mathrm{x}_{\mathrm{L}}$ did not prevent Fas-induced recruitment of pro-caspase-8 to the DISC or its proteolytic activation, but did block activation of at least some downstream effector caspases, loss of mitochondrial membrane potential, and cell death. Although $\mathrm{BCl}-\mathrm{x}_{\mathrm{L}}$ inhibited apoptosis induced by microinjection of proteolytically active caspase-8, its actions are likely to be indirect because it neither interacted with caspase-8 nor inhibited its proteolytic activity. Hence, the precise mechanism by which $\mathrm{BCl}-\mathrm{x}_{\mathrm{L}}$ interrupts death receptor signaling after its initiation is unclear: these actions may represent a new manifestation of one of $\mathrm{BCl}-\mathrm{x}_{\mathrm{L}}$ 's al ready known biological functions or an entirely novel function. N evertheless, these observations, if confirmed in future studies, are singularly important. They suggest that initiation of the caspase proteolytic cascade is not sufficient to commit the cell to an apoptotic demise because the cascade's forward progress can be halted by negative regulators.

\section{Derailing death: endogenous mammalian caspase inhibitors}

As noted earlier, viruses have devised a number of selfserving tactics to prevent the induction of apoptosis in virally infected cells. For instance, the cowpox serpin CrmA and the baculoviral p35 gene product are pseudosubstrate inhibitors of one or more caspases: CrmA inhi bits caspase 1 as well as caspase- 8 and the structurally unrelated serine protease granzyme $\mathrm{B}$ to a lesser extent, whereas p35 is a more promiscuous, broad-spectrum caspase inhibitor (Ray et al . 1992; Komiyama et al. 1994; Bump et al. 1995; Bertin et al. 1996; Quan et al. 1996). These viral gene products incapacitate proteolytically active caspases by remaining tightly bound to the active site following their proteolysis. In contrast, the baculoviral iaps, which can functionally compensate for p35 Ioss (Crook et al. 1993; Clem and Miller 1994), act up- stream of caspases to prevent their activation in insect cells, rather than di rectly inhibiting catalytically active caspases (Manji et al. 1997; Seshagiri and M iller 1997a). They may act by a similar mechanism in mammalian cells to prevent apoptosis induced by overexpression of some pro-caspases, an event that likely requires the endogenous proteolytic activation of the introduced proenzymes (Duckett et al. 1996; Hawkins et al. 1996). The existence of these viral gene products that negatively regulate caspases has led to an intense search for their cellular origins. Although no mammalian genes with sequence homology to crmA or p35 have been identified, a growing family of mammalian iaps has been delineated. To date, this gene family includes naip, xiap/hilp/mi ha, c-iap1/hiap-2/mihb, c-iap2/hiap-1/mihc, and survivin (Rothe et al. 1995; Roy et al. 1995; Duckett et al. 1996; Liston et al. 1996; Uren et al. 1996; Ambrosini et al. 1997). naip was cloned by virtue of its partial deletion in a subgroup of patients with spinal muscular atrophy, an autosomal recessive neurodegenerative disease likely characterized by excessive apoptosis (Roy et al. 1995). C-IAP1 and C-IAP2 were initially isolated by their interaction with TRAF-1 and TRAF- 2 in the TN FR2 receptor complex (Rothe et al. 1995); c-IAP1 is al so recruited to the DISC of TNFR1 by TRAF2 (Shu et al. 1996). Survivin is commonly overexpressed in a number of human malignancies and may contribute to their resistance to apoptosis (Ambrosini et al. 1997). Like the viral iaps, these mammalian iaps all contain at least one aminoterminal baculoviral IAP repeat (BIR); most contain two or three such repeats (survivin has only one). In addition, C-IAP1, c-IAP2, and XIAP (but not NAIP or survivin) have a conserved carboxy-terminal RING finger, zincbinding domain characteristic of the baculoviral IAPs. Overexpression of these mammalian IA Ps confers resistance to apoptotic cell death induced by a broad range of stimuli (Duckett et al. 1996; Liston et al. 1996; U ren et al. 1996; Ambrosini et al. 1997; Duckett et al. 1998); protection against apoptosis requires the BIR domains but not the RIN G finger (Duckett et al. 1998).

Recent studies have begun to elucidate the mechanisms by which at least some of the mammalian IAPs antagonize programmed cell death. XIAP is a potent, active site-directed inhibitor of the effector caspases-3 $\left(\mathrm{K}_{\mathrm{i}} \sim 0.7 \mathrm{nM}\right)$ and $-7\left(\mathrm{~K}_{\mathrm{i}} \sim 0.2 \mathrm{~nm}\right)$, but does not inhibit proteolytically active recombinant caspases-1, -6 , or -8 (Deveraux et al. 1997). This inhibition is mediated by XIAP's BIRs: an XIAP protein containing only its three BIRs also potently inhibited these caspases, whereas the XIAP RING finger was impotent in this regard. XIAP binds specifically to active caspases-3 and -7; it does not bind to their proenzymes. In contrast to the viral caspase inhibitors CrmA and p35, XIAP is not cleaved by these caspases, indicating a distinct mechanism of inhibition. XIAP also inhibits the proteolytic activation of procaspase 3 in cell-free extracts and in Bax-transfected cells, an effect that may reflect inhibition of an upstream caspase (e.g., caspase-9) required for caspase-3 activation and/or disruption of caspase-3's ability to autoprocess (Deveraux et al. 1997). c-IAP1 and c-IAP2 also specifi- 
cally inhibit caspases- 3 and -7 by a BIR-dependent mechanism, although they are profoundly less potent than XIAP (Roy et al. 1997). Curiously, N AIP (an IAP with three BIRs but no RING-finger) does not inhibit caspases-1, $-3,-6,-7$, or -8 , suggesting that it exerts its antiapoptotic actions through inhibition of other caspases or by an entirely distinct mechanism (Roy et al. 1997). Taken together, these findings suggest that some of the mammalian IAPs (especially XIAP) antagonize cell death by acting as endogenous inhibitors of the caspase terminators. As such, the level of their expression may be a determinant of the cell's sensitivity to apoptosis. Currently, little is known about the regulation of expression of these proteins. Moreover, the mammalian IAPs are likely to be multifaceted death antagonists. For instance, C-IAP2, a component of the TNFR1 signaling complex, antagonizes TNF-induced apoptosis by promoting the activation of the prosurvival transcription factor NF-кB (Chu et al. 1997). Furthermore, the existence of these (and other) inhibitors of activated effector caspases may explain the puzzling observation that proteolytically active caspase-3 can be found, at least transiently, in viable, cytokine-activated $\mathrm{T}$ Iymphoctyes (Miossec et al. 1997). Hence, caspases may have important cellular functions in addition to the execution of apoptosis.

A nother endogenous inhibitor of caspases is nitric oxide ( $\mathrm{NO}$ ) and/ or its reactive species, the enzymatic product of multiple NO synthases (eN OS, nN OS, and iNOS) (for review, see Mayer and Hemmens 1997). NO suppresses a diverse range of naturally occurring and induced programmed cell deaths, although it has also been linked to the induction of apoptosis in certain circumstances (Dimmeler and Zeiher 1997; Mannick et al. $1994,1997)$. NO reactive products regulate the activity of proteins by forming reversible thiol adducts (S-nitrosylation) (for review, see Stamler 1994). Recently, several groups have demonstrated that NO species can S-nitrosylate the catalytic cysteine resi due of multiple caspases and thereby incapacitate their proteolytic activity; caspase activity could be restored by the addition of DTT, which removes the bound NO species (Kim et al. 1997b; J. Li et al. 1997; Mohr et al. 1997; Tenneti et al. 1997). Like the caspase inhibitor XIAP, NO also blocks the proteol ytic activation of pro-caspase-3 in vitro and in vivo (Kim et al. 1997b). Hence, modulation of the endogenous production of $\mathrm{NO}$, primarily through its inducible synthase (iNOS), likely influences the cellular apoptotic threshold by regulating caspase activity. Only time will tell whether additional endogenous caspase inhibitors exist, a plausible scenario given the untoward cellular consequences of inappropriate caspase activation.

\section{Death by cleavage}

Foll owing their meticulously guarded activation, the terminator caspases initiate their deadly assault on the cell by selectively cleaving a number of "death substrates." Despite an impressively long list of substrates that are proteolyzed by caspases during apoptosis (see Table 1), the mechanisms by which caspases execute the cell have been entirely elusive until recently. For one thing, the functional significance of the vast majority of these cleavage events is unknown. For the proteolysis of a substrate to contribute functionally to the demise of the cell, it must be cleaved prior to the biochemical and morphological manifestations of apoptotic cell death. In addition, caspase-mediated cleavage must deregulate the activity of its cellular target, either by activating a dormant, proapoptotic protein or inactivating a protein necessary for the cell's structural integrity or survival. Fur-

Table 1. Caspase substrates cleaved during apoptosis

I. Substrates functionally linked to the induction of apoptosis

A. Activation of dormant killers

PKC $\delta$ and $\theta$ (Emoto et al. 1995; Datta et al. 1997)

MEKK-1 (Cardone et al. 1997)

PAK2/hPAK65 (Rudel and Bokoch 1997; Lee et al. 1997)

pro-caspases (for review, Fraser and Evan 1996; Nicholson and Thornberry 1997)

B. Structural dismantling nuclear lamins (Lazebnik et al. 1995; Rao et al. 1996; Takahashi et al. 1996)

Gas2 (Brancolini et al. 1995)

gel solin (Kothakota et al. 1997)

C. Elimination of death antagonists/disruption of the cell death apparatus

BCl-2 (Cheng et al. 1997)

$\mathrm{BCl}-\mathrm{x}_{\mathrm{L}}$ (Clem et al. 1998)

DFF-45/ICAD (Liu et al. 1997; Enari et al. 1998; Sakahira et al. 1998)

p28 Bap31 ( $\mathrm{N} \mathrm{g}$ et al. 1997)

II. Substrates of uncertain functional significance in apoptosis

PARP (Lazebnik et al. 1994)

DNA-PK ${ }_{\text {CS }}$ (Casciola-Rosen et al. 1995; Han et al. 1996; Song et al. 1996)

U1-70kD (Casciola-Rosen et al. 1994, 1996)

hnRP C1 and C2 (Waterhouse et al. 1996)

DSEB/RF-C140 (U beda and Habener 1997; Rhéaume et al. 1997)

Spl (Piedrafita and Pfahl 1997)

fodrin (M artin et al. 1995a; Greidinger et al. 1996; Cryns et al. 1996; Vanags et al. 1996)

actin (M ashima et al. 1995; Kayalar et al. 1996)

keratins (Caulin et al. 1997; Ku et al. 1997)

FAK (Wen et al. 1997)

$\beta$-catenin (Brancolini et al. 1997)

D4-GDI ( $\mathrm{Na}$ et al. 1996)

RB (Janicke et al. 1996; Tan et al. 1997)

PITSLRE kinase (Lahti et al. 1995; Beyaert et al. 1997)

PRK2 (Cryns et al. 1997)

phospholipase $A_{2}$ (Wissing et al. 1997)

IкB- $\alpha$ (Barkett et al. 1997)

rabaptin-5 (Cosulich et al. 1997)

MDM 2 (Chen et al. 1997; Erhardt et al. 1997)

Huntingtin (Goldberg et al. 1996)

presenilins 1 and 2 (Kim et al. 1997a; Loetscher et al .

1997; Vito et al. 1997)

DRPLA (Miyashita et al. 1997)

SREBPs (Wang et al. 1996) 
thermore, inhibiting the proteolysis of a genuine death substrate (by mutating the Asp residue at the caspase cleavage site) should prevent one or more of the characteristic features of apoptosis. Recently, a small number of downstream caspase targets that meet these criteria have been identified by a variety of approaches. Several of these substrates have been isolated by systematic strategies, including purification of specific protein activities from cell-free apoptotic systems (Lee et al. 1997; Liu et al. 1997; Enari et al. 1998; Sakahira et al. 1998) and in vitro expression cloning approaches (Cryns et al. 1997; Kothakota et al. 1997; Lustig et al. 1997). In the remainder of this section, we will examine how the coordinated proteolysis of some of these substrates directly and unambiguously implicates the caspases in the systematic execution of the cell.

Several kinases, including PAK2/hPAK65, PKC isoforms $\delta$ and $\theta$, and MEKK-1, are activated proteolytically by one or more caspases during the induction of apoptosis (Emoto et al . 1995; Ghayur et al. 1996; Cardone et al. 1997; Datta et al. 1997; Lee et al. 1997; Rudel and Bokoch 1997). In each case, caspase cleavage removes an inhibitory amino-terminal regulatory domain, thereby generating a constitutively active kinase. PAK2/hPAK 65 is a widely expressed member of the PAK (p21-activated kinase) family of serine/threonine kinases that bind and transmit signals from the p21 Rho family GTPases Rac1 and C dc42 to the actin cytoskeleton (Knaus et al . 1995; Teo et al. 1995). Overexpression of the PAK2/hPAK65 carboxy-terminal kinase domain generated by caspase cleavage induced cytoplasmic/nuclear condensation, cellular detachment, and phosphatidylserine externalization, hallmark characteristics of apoptosis. Importantly, the induction of apoptosis in this setting was not inhibited by peptide caspase inhibitors, consistent with the hypothesis that kinase activation is downstream of the caspases (Lee et al. 1997). A dominant-negative, caspase cleavage-resistant PAK2/hPAK65 kinase, containing amino acid substitutions at the caspase cl eavage and ATP-binding sites, delayed the induction of apoptosis as monitored by phosphatidylserine exposure (Lee et al. 1997), whereas a dominant-negative PAK 1 construct (with its caspase cleavage site intact) delayed apoptotic membrane blebbing (Rudel and Bokoch 1997). Similarly, MEKK-1, the most upstream kinase in the JNK/SAPK pathway, is cleaved and activated by caspases during apoptosis induced by disruption of cellular contacts with the extracellular matrix (Cardone et al. 1997). Ectopic expression of the caspase-truncated kinase induces apoptosis, whereas the introduction of a mutant MEKK-1 resistant to caspase cleavage suppresses cell death and caspase 7 activation. The latter finding suggests a deathamplifying loop in which caspases activate MEKK-1, which in turn leads to the activation of other caspases (Cardone et al . 1997). Furthermore, overexpression of the activated kinase domains of PKC isoforms $\delta$ and $\theta$ corresponding to their caspase cleavage fragments (but not the intact kinases) al so induces apoptosis (Ghayur et al. 1996; Datta et al. 1997). Hence, kinases are important downstream targets of the caspases whose proteolytic activation likely contributes broadly to the execution of the cell. Although PAK2/hPAK65 and MEKK-1 activate the JNK/SAPK pathway that has been implicated in some apoptotic cell deaths (Xia et al. 1995; Chen et al. 1996; Verheij et al. 1996), the substrates of these killer kinases are largely unknown.

In addition to modulating the activity of key regulatory proteins such as kinases, caspases proteol yze a number of structural proteins. One such target is gel solin, a cytoskeletal protein that organizes the actin filament network (Kwiatkowski et al. 1986). Gelsolin is rapidly cleaved by a caspase-3-like protease during Fas- and TNF-induced apoptosis to yield an amino-terminal cleavage fragment that, unlike full-length gelsolin, is capable of disrupting actin filaments in the absence of calcium and inducing apoptosis (Kothakota et al. 1997). These actions of the proapoptotic gelsolin cleavage fragment were not affected by caspase inhibitors: Once gelsolin is cleaved, caspases are no longer required. Moreover, neutrophils from gelsolin-deficient mice were resistant to TN F $\alpha$ - and Fas-induced apoptosis, confirming that gelsolin cleavage promotes cell death (Kothakota et al. 1997). Similarly, caspase cleavage of the microfilament protein Gas2 leads to profound disturbances of the actin cytoskeleton, cellular rounding up, and cytoplasmic condensation, thereby implicating its proteolysis in these apoptotic events (Brancolini et al. 1995). In addition, the nuclear lamins, important structural elements of the nuclear envelope, are cleaved in their conserved $\alpha$-helical rod domain by caspase 6 during PCD (Lazebnik et al. 1995; Orth et al. 1996; Rao et al. 1996; Takahashi et al. 1996). Introduction of caspase cleavage-resistant lamins into cells prevents or delays the appearance of many of the nuclear manifestations of apoptosis, including chromatin condensation, oligonucleosomal DNA fragmentation, and apoptotic body formation (Rao et al. 1996). These observations indicate that caspase cleavage of the nuclear lamins is linked causally to the disassembly of the nucleus during apoptotic cell death, and may facilitate DNA fragmentation indirectly, perhaps by providing endonucleases access to the nucleus.

Indeed, caspases play an essential role in the internucleosomal DNA laddering that typifies apoptotic cell death by activating a latent, cytosolic endonuclease, CAD (caspase-activated deoxyribonuclease) (Enari et al. 1998; Sakahira et al. 1998). CAD is normally sequestered in the cytoplasm via its binding to an inhibitor (ICAD/DFF-45), which suppresses its endonuclease activity and conceals its nuclear localization signal (Liu et al. 1997; Enari et al. 1998; Sakahira et al . 1998). ICAD / DFF-45 is expressed as two alternatively spliced isoforms. The corresponding gene products both bind to and inhibit CAD. During the induction of apoptosis, ICAD/DFF-45 (both long and short forms) is cleaved and inactivated by a caspase-3-like protease, thereby resulting in the activation of CAD, its nuclear translocation and subsequent oligonucleosomal DNA fragmentation. Of note, CAD may require additional cytosolic factors to degrade DNA: It has yet to be demonstrated whether 
recombinant CAD has endonuclease activity. Overexpression of wild-type or caspase cleavage-resistant ICAD/DFF-45 protects cells from apoptotic DNA fragmentation but does not prevent phosphatidylserine externalization, mitochondrial injury, or cleavage of other caspase targets, again indicating that ICAD/DFF-45 is but one of several downstream caspase targets (Enari et al. 1998; Sakahira et al. 1998). Nevertheless, this elegantly simple strategy directly couples caspase activation to DNA degradation, the details of which are currently being worked out.

$\mathrm{BCl}-2$ and $\mathrm{BCl}-\mathrm{x}_{\mathrm{L}}$, two antiapoptotic $\mathrm{BCl}-2$ family members, are also cleaved by caspases, at least during some types of apoptotic cell deaths (Cheng et al. 1997; Clem et al. 1998; Grandgirard et al. 1998). Both are cleaved in their amino-terminal loop domains: $\mathrm{Bcl}-2$ by a caspase3-like protease and $\mathrm{BCl}-\mathrm{x}_{\mathrm{L}}$ by a caspase-1-like family member. Caspase cleavage generates a carboxy-terminal fragment with radically different properties from their full-length counterparts: They promote rather than antagonize cell death. Furthermore, expression of mutant $\mathrm{BCl}-2$ and $\mathrm{BCl}-\mathrm{x}_{\mathrm{L}}$ proteins resistant to caspase cleavage conferred greater protection against apoptotic stimuli than did the wild-type proteins. These findings suggest that caspase cleavage of these antiapoptotic proteins (with its consequent removal of their amino-terminal $\mathrm{BH} 4$ domains) transforms them into killers. Interestingly, death induced by overexpression of either the $\mathrm{BCl}-2$ or $\mathrm{BCl}-\mathrm{x}_{\mathrm{L}}$ carboxy-terminal fragments is suppressed by the broad-spectrum caspase inhi bitor p35, thereby implicating them in a death-amplifying loop in which caspase cleavage of these $\mathrm{Bcl}-2$ family members begets more caspase activation, and so on. Hence, proteolytic elimination of death antagonists may be a general theme in apoptosis.

These studies, then, provide unequivocal evidence that caspase-mediated proteolysis of specific intracellular targets is both necessary and sufficient to produce many of the characteristic features of apoptosis. No doubt, additional caspase targets (perhaps, even some listed in Table 1) will be linked functionally to these and other apoptotic events. However, a major challenge will be to understand on a more detailed level how these seemingly chaotic, multiple proteolytic events (executed presumably by multiple caspases) collectively produce a very ordered series of cellular changes culminating in death. Moreover, it is unclear whether caspase proteolysis is responsible for all aspects of apoptotic cell death, or whether caspase-independent apoptotic phenomena exist. Recent studies suggest that apoptosis triggered by some stimuli (e.g., overexpression of proapoptotic Bcl-2 family members) involves components (membrane blebbing/permeability alterations, loss of the mitochondrial membrane potential and generation of reactive oxygen species) that are refractory to caspase inhibition (Xiang et al. 1996; McCarthy et al. 1997). In these settings, caspase inhibitors do not prevent cell death; death proceeds in a delayed/atypical fashion. These issues are not merely of academic interest, but have a direct bearing on the potential efficacy of thera- peutic strategies designed to eliminate cell death by inhibiting caspases.

\section{Future directions}

The field of apoptosis research appears to be advancing by an ampl ifying cascade of discoveries: One finding rapidly catalyzes another (and leads to the recruitment of yet another investigator into the field). N evertheless, there are many gaps in our understanding of the molecular details of caspase activation and the multifaceted cellular defenses against inappropriate activation of these lethal proteases. Moreover, we have identified only a limited number of functionally relevant downstream caspase targets whose proteolysis ultimately kills the cell; the number and identity of additional such targets has yet to be determined. Cleavage of each one of these caspase substrates presumably deregulates signaling pathways that contribute to one or more components of apoptosis. However, for most of the substrates linked to the execution of death, these subsequent events are entirely unknown.

Given the likelihood that dysregulated apoptosis contributes to many disease processes, caspase-directed therapies may prove to be of clinical utility in a variety of disorders (for review, see Thompson 1995; N icholson 1996; Cryns and Yuan 1998). At least in principle, the deficient cell death that characterizes cancer might be corrected by the selective delivery of activated caspases into neoplasms by gene therapy. In contrast, the excessive cell death characteristic of neurodegenerative disorders, strokes, and myocardial infarctions might be prevented or attenuated by treatment with sel ective caspase inhibitors. Indeed, several studies have demonstrated that pre- or early treatment of animals with peptide caspase inhibitors can dramatically reduce brain infarcts induced by middle cerebral artery occlusion (with or without reperfusion) and improve neurologic outcome (Loddick et al. 1996; Hara et al. 1997). However, the therapeutic window appears to be quite short: Treatment initiated even $1 \mathrm{hr}$ after the onset of reperfusion provided no significant protection (Hara et al . 1997). Similar studies in an animal model of myocardial infarction revealed less striking effects despite an almost fourfold reduction in the number of apoptotic myocytes (Y aoita et al . 1998). Finally, neuronal expression of a dominant negative caspase-1 transgene confers resistance to focal cerebral ischemia and delays the progression of neuromuscular weakness and death in SOD-1 transgenic mice (Friedlander et al . 1997a,b). Taken together, these findings suggest that caspases may, indeed, prove to be important therapeutic targets, particularly with the advent of potent, cell-permeable, nonpeptide inhi bitors and improvements in gene therapy. Nevertheless, it remains to be seen whether prolonged caspase inhibition will continue to preserve the functional integrity of salvaged cells and whether such inhibition does not, itself, result in adverse consequences. 


\section{Acknowledgments}

We are indebted to Drs. R. Talanian, Z. Oltvai, and L. Bergeron for their careful reading and criticisms of this review. This work was supported in part by a Mentored Clinical Scientist Development Award K08-CA01752 (to V.L.C.) and grants AG12859 and RS34817 (to J.Y.) from the $\mathrm{N}$ ational Institutes of Health, an American Heart Established Investigator A ward (to J.Y.), and by institutional research grants to N orthwestern University from the American Cancer Society and the Howard Hughes M edical Institute (to V.L.C.).

\section{References}

Ahmad, M., S.M. Srinivasula, L. Wang, R.V. Talanian, G. Litwack, T. Fernandes-Alnemri, and E. Alnemri. 1997. CRADD, a novel human apoptotic adaptor molecule for caspase-2, and FasL/tumor necrosis factor receptor-interacting protein RIP. Cancer Res. 57: 615-619.

Alnemri, E.S., D.J. Livingston, D.W. Nicholson, G. Salvesen, N.A. Thornberry, W.W. Wong, and J. Yuan. 1996. Human ICE/CED-3 protease nomenclature. Cell 87: 171.

Ambrosini, G., C. Adida, and D.C. Altieri. 1997. A novel antiapoptosis gene, survivin, expressed in cancer and lymphoma. Nature Med. 3: 917-921.

Antonsson, B., F. Conti, A. Ciavatta, S. Montessuit, S. Lewis, I. Martinou, L. Bernasconi, A. Bernard, J.-J. Mermod, G. Mazzei, K. M aundrell, F. Gambale, R. Sadoul, and J.-C. M artinou. 1997. Inhibition of Bax channel-forming activity by Bcl-2. Science 277: 370-372.

Armstrong, R.C., T. Aja, J. Xiang, S. Gaur, J.F. Krebs, K. Hoang, X. Bai, S.J. Korsmeyer, D.S. Karanewsky, L.C. Fritz, and K.J. Tomaselli. 1996. Fas-induced activation of the cell deathrel ated protease CPP32 is inhibited by $\mathrm{Bcl}-2$ and by ICE family protease inhibitors. J. Biol. Chem. 271: 16850-16855.

Barkett, M., D. Xue, H.R. Horvitz, and T.D. Gilmore. 1997. Phosphorylation of $1 \kappa B-\alpha$ inhibits its cleavage by caspase CPP32 in vitro. J. Biol. Chem. 272: 29419-29422.

Bergeron, L., G.I. Perez, G. M cD onald, L. Shi, Y. Sun, A. Jurisicova, S. Varmuza, K.E. Latham, J.A. Flaws, J.C.M. Salter, H. Hara, M.A. M oskowitz, E. Li, A.H. Greenberg, J. Tilly, and J. Yuan. 1998. Defects in regulation of apoptosis in caspase-2deficient mice. Genes \& Dev. 12: 1304-1314.

Bertin, J., S.M. M endrysa, D.J. LaCount, S. Gaur, J.F. Krebs, R.C. Armstrong, K.J. Tomaselli, and P.D. Friesen. 1996. Apoptotic suppression by baculovirus P35 involves cleavage by and inhibition of a virus-induced CED-3/ICE-like protease. J. Virol. 70: 6251-6259.

Bertin, J., R. Armstrong, S. Ottilie, D. Martin, Y. Wang, S. Banks, G. Wang, T. Senkevich, E. Alnemri, B. Moss, M. Le nardo, K. Tomaselli, and J. Cohen. 1997. Death effector domain-containing herpesvirus and poxvirus proteins inhibit both Fas- and TNFR1-induced apoptosis. Proc. Natl. Acad. Sci. 94: 1172-1176.

Beyaert, R., V.J. Kidd, S. Cornelis, M. Van de Craen, G. Denecker, J.M. Lahti, R. Gururajan, P. Vandenabeele, and W. Fiers. 1997. Cleavage of PITSLRE kinases by ICE/CASP-1 and CPP32/CASP-3 during apoptosis induced by tumor necrosis factor. J. Biol. Chem. 272: 11694-11697.

Boise, L.H. and C.B. Thompson. 1997. BCl- $\mathrm{X}_{\mathrm{L}}$ can inhibit apoptosis in cells that have undergone Fas-induced protease activation. Proc. Natl. Acad. Sci. 94: 3759-3764.

Boldin, M.P., T.M. Goncharov, Y.V. Goltsev, and D. Wallach. 1996. Involvement of MACH, a novel MORT1/FADD-interacting protease, in Fas/APO-1- and TNF receptor-induced cell death. Cell 85: 803-815.
Boldin, M.P., E.E. Varfolomeev, Z. Pancer, I.L. M ett, J.H. Camonis, and D. Wallach. 1995. A novel protein that interacts with the death domain of Fas/APO-1 contains a sequence motif related to the death domain. J. Biol. Chem. 270: 77957798.

Bossy-Wetzel, E., D.D. Newmeyer, and D.R. Green. 1998. Mitochondrial cytochrome $c$ release in apoptosis occurs upstream of DEVD-specific caspase activation and independently of mitochondrial transmembrane depolarization. EMBO J. 17: 37-49.

Boudreau, N., C.J. Sympson, Z. Werb, and M.J. Bissell. 1995. Suppression of ICE and apoptosis in mammary epithelial cells by extracellular matrix. Science 267: 891-893.

Brancolini, C., M. Benedetti, and C. Schneider. 1995. Microfilament reorganization during apoptosis: The role of Gas2, a possible substrate for ICE-like proteases. EMBO J. 14: 51795190.

Brancolini, C., D. Lazarevic, and C. Schneider. 1997. Dismantling cell-cell contacts during apoptosis is coupled to a caspase-dependent proteolytic cleavage of $\beta$-catenin. J. Cell. Biol. 139: 759-771.

Bump, N.J., M. Hackett, M. Hugunin, S. Seshagiri, K. Brady, P. Chen, C. Ferenz, S. Franklin, T. Ghayur, P. Li, P. Licari, J. Mankovich, L. Shi, A.H. Greenberg, L.K. Miller, and W.W. Wong. 1995. Inhibition of ICE family proteases by baculovirus antiapoptotic protein p35. Science 269: 1885-1888.

Cardone, M.H., G.S. Salvesen, C. Widmann, G. Johnson, and S.M. Frisch. 1997. The regulation of anoikis: MEKK-1 activation requires cleavage by caspases. Cell 90: 315-323.

Casciola-Rosen, L.A., D.K. Miller, G.J. Anhalt, and A. Rosen. 1994. Specific cleavage of the 70-kDa protein component of the $U 1$ small nuclear ribonucleoprotein is a characteristic biochemical feature of apoptotic cell death. J. Biol. Chem. 269: 30757-30760.

Casciola-Rosen, L.A., G.J. Anhalt, and A. Rosen. 1995. DNAdependent protein kinase is one of a subset of autoantigens specifically cleaved early during apoptosis. J. Exp. Med. 182: 1625-1634.

Casciola-Rosen, L., D.W. Nicholson, T. Chong, K.R. Rowan, N.A. Thornberry, D.K. Miller, and A. Rosen. 1996. A popain/ CPP32 cleaves proteins that are essential for cellular repair: A fundamental principle of apoptotic death. J. Exp. Med. 183: 1957-1964.

Caulín, C., G.S. Salvesen, and R.G. Oshima. 1997. Caspase cleavage of keratin 18 and reorganization of intermediate filaments during epithelial cell apoptosis. J. Cell Biol. 138: 1379-1394.

Cerretti, D.P., C.J. Kozlosky, B. Mosley, N. Nelson, K. Van Ness, T.A. Greenstreet, C.J. March, S.R. Kronheim, T. Druck, L.A. Cannizzaro, K. Huebner, and R.A. Black. 1992. $\mathrm{M}$ olecular cloning of the interleukin-1 $\beta$ converting enzyme. Science 256: 97-100.

Chaudhary, P.M., M. Eby, A. Jasmin, A. Bookwalter, J. M urray, and L. Hood. 1997. Death receptor 5, a new member of the TNFR family, and DR4 induce FADD-dependent apoptosis and activate the N F-кB. Immunity 7: 821-830.

Chauhan, D., P. Pandey, A. Ogata, G. Teoh, N. Krett, R. Halgren, S. Rosen, D. Kufe, S. Kharbanda, and K. Anderson. 1997. Cytochrome c-dependent and-independent induction of apoptosis in multiple myeloma cells. J. Biol. Chem. 272: 29995-29997.

Chen, L., V. M arechal, J. M oreau, A.J. Levine, and J. Chen. 1997. Proteolytic cleavage of the $\mathrm{mdm} 2$ oncoprotein during apoptosis. J. Biol. Chem. 272: 22966-22973.

Chen, Y.R., C.F. Meyer, and T.H. Tan. 1996. Persistent activation of c-Jun $\mathrm{N}$-terminal kinase 1 (JNK1) in gamma radia- 
tion-induced apoptosis. J. Biol. Chem. 271: 631-634.

Cheng, E.H.Y., D.G. Kirsch, R.J. Clem, R. Ravi, M.B. Kastan, A. Bedi, K. Ueno, and J.M. Hardwick. 1997. Conversion of Bcl-2 to a Bax-like death effector by caspases. Science 278: 19661968.

Chinnaiyan, A.M., K. O'Rourke, M. Tewari, and V.M. Dixit. 1995. FADD, a novel death domain-containing protein, interacts with the death domain of Fas and initiates apoptosis. Cell 81: 505-512.

Chinnaiyan, A.M., K. O'Rourke, G.-L. Yu, R.H. Lyons, M. Garg, D.R. Duan, L. Xing, R. Gentz, J. Ni, and V.M. Dixit. 1996a. Signal transduction by DR3, a death domain-containing re ceptor related to TN FR-1 and CD95. Science 274: 990-992.

Chinnaiyan, A.M., K. Orth, K. O'Rourke, H. Duan, G.G. Poirier, and V.M. Dixit. 1996b. M olecular ordering of the cell death pathway. BCl-2 and $\mathrm{BCl}-\mathrm{X}_{\mathrm{L}}$ function upstream of the CED-3like apoptotic proteases. J. Biol. Chem. 271: 4573-4576.

Chinnaiyan, A.M., C.G. Tepper, M.F. Seldin, K. O'Rourke, F.C. Kischkel, S. Hellbardt, P.H. Krammer, M.E. Peter, and V.M. Dixit. 1996c. FADD/MORT1 is a common mediator of CD95 (Fas/APO-1) and tumor necrosis factor receptor-induced apoptosis. J. Biol. Chem. 271: 4961-4965.

Chinnaiyan, A.M., D. Chaudhary, K. O'Rourke, E.V. Koonin, and V.M. Dixit. 1997a. Role of CED-4 in the activation of CED-3. Nature 388: 728-729.

Chinnaiyan, A.M., K. O'Rourke, B.R. Lane, and V.M. Dixit. 1997b. Interaction of CED-4 with CED-3 and CED-9: a molecular framework for cell death. Science 275: 1122-1126.

Chu, Z.-L., T.A. McKinsey, L. Liu, J.J. Gentry, M.H. Malim, and D.W. Ballard. 1997. Suppression of tumor necrosis factorinduced cell death by inhibitor or apoptosis C-IAP2 is under N F-кB control. Proc. Natl. Acad. Sci. 94: 10057-1062.

Clem, R.J. and L.K. Miller. 1994. Control of programmed cell death by the baculovirus genes p35 and iap. Mol. Cell. Biol. 14: $5212-5222$.

Clem, R., E. Cheng, C. Karp, D. Kirsch, K. Ueno, A. Takahashi, M. Kastan, D. Griffin, W. Earnshaw, M. Veliuona, and J. Hardwick. 1998. Modulation of cell death by $\mathrm{Bcl}-\mathrm{x}_{\mathrm{L}}$ through caspase interaction. Proc. Natl. Acad. Sci. 95: 554-559.

Cosulich, S.C., H. Horiuchi, M. Zerial, P.R. Clarke, and P.G. Woodman. 1997. Cleavage of rabaptin-5 blocks endosome fusion during apoptosis. EMBO J. 16: 6182-6191.

Crook, N.E., R.J. Clem, and L.K. Miller. 1993. An apoptosisinhibiting baculovirus gene with a zinc finger-like motif. J. Virol. 67: 2168-2174.

Cryns, V. and J. Yuan. 1998. The cutting edge: Caspases in apoptosis and disease. In When cells die: A comprehensive evaluation of apoptosis and programmed cell death (ed. Z. Zakeri, J. Tilly, and R. Lockshin), pp. 177-210. John Wiley \& Sons, New York, NY.

Cryns, V.L., L. Bergeron, H. Zhu, H. Li, and J. Yuan. 1996. Specific cleavage of $\alpha$-fodrin during Fas- and tumor necrosis factor-induced apoptosis is mediated by an interleukin$1 \beta$-converting enzyme/Ced-3 protease distinct from the poly(ADP-ribose) polymerase protease. J. Biol. Chem. 271: 31277-31282.

Cryns, V., Y. Byun, A. Rana, H. M ellor, K. Lustig, P. Parker, M. Kirschner, and J. Yuan. 1997. Specific proteolysis of the kinase protein kinase $\mathrm{C}$-related kinase 2 by caspase 3 during apoptosis: Identification by a novel small pool expression cloning strategy. J. Biol. Chem. 272: 29449-29453.

Datta, R., H. Kojima, K. Yoshida, and D. Kufe. 1997. Caspase3-mediated cleavage of protein kinase $\mathrm{C} \theta$ in induction of apoptosis. J. Biol. Chem. 272: 20317-20320.

Degli-Esposti, M.A., W.C. Dougall, P.J. Smolak, J.Y. Waugh, C.A. Smith, and R.G. Goodwin. 1997. The novel receptor
TRAIL-R4 induces N F-кB and protects against TRAIL-mediated apoptosis, yet retains an incomplete death domain. Immunity 7: 813-820.

Deveraux, Q.L., R. Takahashi, G.S. Salvesen, and J.C. Reed. 1997. X-linked IAP is a direct inhibitor of cell-death proteases. Nature 388: 300-304.

Dimmeler, S. and A.M. Zeiher. 1997. Nitric oxide and apoptosis: Another paradigm for the double-edged role of nitric oxide. Nitric Oxide 1: 275-281.

Duan, H. and V.M. Dixit. 1997. RAIDD is a new 'death' adaptor molecule. Nature 385: 86-89.

Duan, H., A.M. Chinnaiyan, P.L. Hudson, J.P. Wing, W.-W. He, and V.M. Dixit. 1996. ICE-LAP3, a novel mammalian homologue of the Caenorhabditis el egans cell death protein Ced-3 is activated during Fas- and tumor necrosis factor-induced apoptosis. J. Biol. Chem. 271: 1621-1625.

Duckett, C.S., V.E. Nava, R.W. Gedrich, R.J. Clem, J.L. Van Dongen, M.C. Gilfillan, H. Shiels, J.M. Hardwick, and C.B. Thompson. 1996. A conserved family of cellular genes related to the baculovirus iap gene and encoding apoptosis inhibitors. EMBO J. 15: 2685-2694.

Duckett, C.S., F. Li, Y. Wang, K.J. Tomaselli, C.B. Thompson, and R.C. Armstrong. 1998. Human IAP-like protein regulates programmed cell death downstream of $\mathrm{Bcl}-\mathrm{x}_{\mathrm{L}}$ and $\mathrm{cy}-$ tochrome c. Mol. Cell. Biol. 18: 608-615.

Emoto, Y., Y. M anome, G. M einhardt, H. Kisaki, S. Kharbanda, M. Robertson, T. Ghayur, W.W. Wong, R. Kamen, R. Weichsel baum, and D. Kufe. 1995. Proteolytic activation of protein kinase $C \delta$ by an ICE-like protease in apoptotic cells. EMBO J. 14: 6148-6156.

Enari, M., H. Hug, and S. N agata. 1995. Involvement of an ICElike protease in Fas-mediated apoptosis. Nature 375: 78-81.

Enari, M., R.V. Talanian, W.W. Wong, and S. N agata. 1996. Sequential activation of ICE-like and CPP32-like proteases during Fas-mediated apoptosis. Nature 380: 723-726.

Enari, M., H. Sakahira, H. Yokoyama, K. Okawa, A. Iwamatsu, and S. Nagata. 1998. A caspase-activated DN ase that degrades DNA during apoptosis, and its inhibitor ICAD. Nature 391: 43-50.

Erhardt, P., K. Tomaselli, and G. Cooper. 1997. Identification of the MDM 2 oncoprotein as a substrate for CPP32-like apoptotic proteases. J. Biol. Chem. 272: 15049-15052.

Fal eiro, L., R. Kobayashi, H. Fearnhead, and Y. Lazebnick. 1997. Multiple species of CPP32 and Mch2 are the major active caspases present in apoptotic cells. EMBO J. 16: 2271-2281.

Fernandes-AInemri, T., G. Litwack, and E.S. Alnemri. 1994. CPP32, a novel human apoptotic protein with homology to Caenorhabditis el egans cell death protein ced-3 and mammalian interleukin-1B-converting enzyme. J. Biol. Chem. 269: 30761-30764.

Fernandes-AInemri, T., R.C. Armstrong, J. Krebs, S.M. Srinivasula, L. Wang, F. Bullrich, L.C. Fritz, J.A. Trapani, K.J. Tomaselli, G. Litwack, and E.S. Alnemri. 1996. In vitro activation of CPP32 and M ch3 by M ch4, a novel apoptotic cysteine protease containing two FADD-like domains. Proc. Natl. Acad. Sci. 93: 7464-7469.

Fraser, A. and G. Evan. 1996. A license to kill. Cell 85: 781-784.

Friedlander, R.M., V. Gagliardini, R.J. Rotello, and J. Yuan. 1996. Functional role of interleukin $1 \beta$ (IL-1 $\beta$ ) in IL-1 $\beta$-converting enzyme-mediated apoptosis. J. Exp. Med. 184: 717724.

Friedlander, R.M., R.H. Brown, V. Gagliardini, J. Wang, and J. Yuan. 1997a. Inhibition of ICE slows ALS in mice. Nature 388: 31.

Friedlander, R.M., V. Gagliardini, H. Hara, K.B. Fink, W. Li, G. MacDonald, M.C. Fishman, A.H. Greenberg, M.A. M oskow- 
itz, and J. Yuan. 1997b. Expression of a dominant negative mutant of interleukin-1 $\beta$ converting enzyme in transgenic mice prevents neuronal cell death induced by trophic factor withdrawal and ischemic brain injury. J. Exp. Med. 185: 933940.

Gagliardini, V., P.-A. Fernandez, R.K.K. Lee, H.C.A. Drexler, R.J. Rotello, M.C. Fishman, and J. Yuan. 1994. Prevention of vertebrate neuronal death by the crmA gene. Science 263: 826-828.

Ghayur, T., M. Hugunin, R.V. Talanian, S. Ratnofsky, C. QuinIan, Y. Emoto, P. Pandey, R. Datta, Y. Huang, S. Kharbanda, H. Allen, R. Kamen, W. Wong, and D. Kufe. 1996. Proteolytic activation of protein kinase $C \delta$ by an ICE/CED 3-like protease induces characteristics of apoptosis. J. Exp. Med. 184: 2399-2404.

Goldberg, Y.P., D.W. Nicholson, D.M. Rasper, M.A. Kalchman, H.B. Koide, R.K. Graham, M. Bromm, P. Kazemi-Esfarjani, N .A. Thornberry, J.P. Vaillancourt, and M.R. Hayden. 1996. Cleavage of huntingtin by apopain, a proapoptotic cysteine protease, is modulated by the polyglutamine tract. Nature Genet. 13: 442-449.

Golstein, P. 1997a. Controlling cell death. Science 275: 10811082.

- - . 1997b. TRAIL and its receptors. Curr. Biol. 7: R750R753.

Goltsev, Y.V., A.V. Kovalenko, E. Arnold, E.E. Varfolomeev, V.M. Brodianksi, and D. Wallach. 1997. CASH, a novel caspase homol og with death effector domains. J. Biol. Chem. 272: 19641-19644.

Gottlieb, R.A., J. N ordberg, E. Skowronski, and B.M. Babior. 1996. A poptosis induced in Jurkat cells by several agents is preceded by intracellular acidification. Proc. Natl. Acad. Sci. 93: 654-658.

Grandgirard, D., E. Studer, L. Monney, T. Belser, I. Fellay, C. Borner, and M.R. Michel. 1998. Alphaviruses induce apoptosis in Bcl-2-overexpressing cells: Evidence for a caspasemediated, proteolytic inactivation of $\mathrm{Bcl}-2$. EMBO J. 17: 1268-1278.

Greidinger, E.L., D.K. Miller, T.-T. Yamin, L. Casciola-Rosen, and A. Rosen. 1996. Sequential activation of three distinct ICE-like activities in Fas-ligated Jurkat cells. FEBS Lett. 390: 299-303.

Han, D.K.M., P.M. Chaudhary, M.E. Wright, C. Friedman, B.J. Trask, R.T. Riedel, D.G. Baskin, S.M. Schwartz, and L. Hood. 1997. MRIT, a novel death-effector domain-containing protein, interacts with caspases and $\mathrm{BClXL}$ and initiates cell death. Proc. Natl. Acad. Sci. 94: 11333-11338.

Han, Z., N. Malik, T. Carter, W.H. Reeves, J.H. Wyche, and E.A. Hendrickson. 1996. DNA-dependent protein kinase is a target for a CPP32-like apoptotic protease. J. Biol. Chem. 271: 25035-25040.

Hara, H., R.M. Friedlander, V. Gagliardini, C. Ayata, K. Fink, Z. Huang, M. Shimizu-Sasamata, J. Yuan, and M.A. Moskowitz. 1997. Inhibition of interleukin $1 \beta$ converting enzyme family proteases reduces ischemic and excitotoxic neuronal damage. Proc. Natl. Acad. Sci. 94: 2007-2012.

Hawkins, C.J., A.G. Uren, G. Hacker, R.L. Medcalf, and D.L. Vaux. 1996. Inhibition of interleukin $1 \beta$-converting enzyme-mediated apoptosis of mammalian cells by baculovirus IAP. Proc. Natl. Acad. Sci. 93: 13786-13790.

Hengartner, M. 1997. CED-4 is a stranger no more. Nature 388: $714-715$.

- - . 1998. Death cycle and Swiss army knives. Nature 391: 441.

Hengartner, M.O. and H.R. Horvitz. 1994. C. elegans cell survival gene ced- 9 encodes a functional homolog of the mam- malian proto-oncogene bcl-2. Cell 76: 665-676.

Hengartner, M., R.E. Ellis, and H.R. Horvitz. 1992. Caenorhabditis el egans gene ced- 9 protects cells from programmed cell death. Nature 356: 494-499.

Hockenbery, D.M., Z.N. Oltvai, X.-M. Yin, C.L. Milliman, and S.J. Korsmeyer. 1993. Bcl-2 functions in an antioxidant pathway to prevent apoptosis. Cell 75: 241-251.

Hofmann, K., P. Bucher, and J. Tschopp. 1997. The CARD domain: A new apoptotic signalling motif. Trends Biochem. Sci. 22: 155-156.

Hsu, H., J. Xiong, and D.V. Goeddel. 1995. The TN F receptor1associated protein TRADD signals cell death and NF-кB activation. Cell 81: 495-504.

Hsu, H., H.-B. Shu, M.-P. Pan, and D.V. Goeddel. 1996. TRADDTRAF2 and TRADD-FADD interactions define two distinct TNF receptor-1 signal transduction pathways. Cell 84: 299308.

Hu, S., C. Vincenz, J. Ni, R. Gentz, and V.M. Dixit. 1997. I-FLICE, a novel inhibitor of tumor necrosis factor receptor-1 and CD-95-induced apoptosis. J. Biol. Chem. 272: 1725517257.

Inohara, N., T. Koseki, Y. Hu, S. Chen, and G. N úñez. 1997. CLARP, a death effector domain-containing protein interacts with caspase-8 and regulates apoptosis. Proc. Natl. Acad. Sci. 94: 10717-10722.

Irmler, M., K. H ofmann, D. Vaux, and J. Tschopp. 1997a. Direct physical interaction between the Caenorhabditis elegans "death proteins" CED-3 and CED-4. FEBS Lett. 406: 189190.

Irmler, M., M. Thome, M. Hahne, P. Schneider, K. Hofmann, V. Steiner, J.-L. Bodmer, M. Schröter, K. Burns, C. Mattmann, D. Rimoldi, L. French, and J. Tschopp. 1997b. Inhibition of death receptor signals by cellular FLIP. Nature 388: 190-195.

Janicke, R.U., P.A. Walker, X.Y. Lin, and A.G. Porter. 1996. Specific cleavage of the retinoblastoma protein by an ICElike protease in apoptosis. EMBO J. 15: 6969-7698.

Kayal ar, C., T. Örd, M .P. Testa, L.-T. Zhong, and D.E. Bredesen. 1996. Cleavage of actin by interleukin 1 $\beta$-converting enzyme to reverse DN ase I inhibition. Proc. Natl. Acad. Sci. 93: 2234-2238.

Kerr, J.F.R., A.H. Wyllie, and A.R. Currie. 1972. A poptosis: A basic biological phenomenon with wide-ranging implication in tissue kinetics. Br. J. Cancer 26: 239-257.

Kharbanda, S., P. Pandey, L. Schofield, S. Israels, R. Roncinske, K. Yoshida, A. Bharti, Z.M. Yuan, S. Saxena, R. Weichselbaum, C. Nalin, and D.W. Kufe. 1997. Role for $B C l-x_{L}$ as an inhibitor of cytosolic cytochrome $c$ accumulation in DNAdamage induced apoptosis. Proc. Natl. Acad. Sci. 94: 69396942.

Kim, T.-W., W.H. Pettingell, Y.-K. Jung, D.M. Kovacs, and R.E. Tanzi. 1997a. Alternative cleavage of Alzheimer-associated presenilins during apoptosis by a caspase- 3 family protease. Science 277: 373-376.

Kim, Y.-M., R.V. Talanian, and T.R. Billiar. 1997b. Nitric oxide inhibits apoptosis by preventing increases in caspase-3-like activity via two distinct mechanisms. J. Biol. Chem. 272: 31138-31148.

Kitson, J., T. Raven, Y.-P. Jiang, D.V. Goeddel, K.M. Giles, K.-T. Pun, C.J. Grinham, R. Brown, and S.N. Farrow. 1996. A death-domain-containing receptor that mediates apoptosis. Nature 384: 372-375.

Kluck, R.M., E. Bossy-Wetzel, D.R. Green, and D.D. N ewmeyer. 1997a. The release of cytochrome $c$ from mitochondria: A primary site for $\mathrm{Bcl}-2$ regulation of apoptosis. Science 275: 1132-1136.

Kluck, R.M., S.J. Martin, B.M. Hoffman, J.S. Zhou, D.R. Green, 
and D.D. Newmeyer. 1997b. Cytochrome c activation of CPP32-like proteolysis plays a critical role in a Xenopus cellfree apoptosis system. EMBO J. 16: 4639-4649.

Knaus, U., S. M orris, H. Dong, J. Chernoff, and G. Bokoch. 1995. Regulation of human leukocyte p21-activated kinases through G-protein-coupled receptors. Science 269: 221-223.

Komiyama, T., C.A. Ray, D.J. Pickup, A.D. Howard, N.A. Thornberry, E.P. Peterson, and G. Salvesen. 1994. Inhibition of the interleukin-1 $\beta$ converting enzyme by the cowpox virus serpin CrmA. An example of cross-class inhibition. J. Biol. Chem. 269: 19331-19337.

Kothakota, S., T. Azuma, C. Reinhard, A. Klippel, J. Tang, K. Chu, T.J. McGarry, M.W. Kirschner, K. Koths, D.J. Kwiatkowski, and L.T. Williams. 1997. Caspase-3-generated fragment of gelsolin: Effector of morphological change in apoptosis. Science 278: 294-298.

Krajewski, S., S. Tanaka, S. Takayama, M.J. Schibler, W. Fenton, and J.C. Reed. 1993. Investigation of the subcellular distribution of the $\mathrm{Bcl}-2$ oncoprotein: Residence in the nuclear envelop, endoplasmic reticulum, and the outer mitochondrial membranes. Cancer Res. 53: 4701-4714.

Ku, N.-O., J. Liao, and M.B. Omary. 1997. A poptosis generates stable fragments of human type I keratins. J. Biol. Chem. 272: 33197-33203.

Kuida, K., J.A. Lippke, G. Ku, M.W. Harding, D.J. Livingston, M.S.-S. Su, and R.A. Flavell. 1995. Altered cytokine export and apoptosis in mice deficient in interleukin-1 $\beta$ converting enzyme. Science 267: 2000-2002.

Kuida, K., T.S. Zheng, S. Na, C.-y. Kuan, D. Yang, H. Karasuyama, P. Rakic, and R.A. Flavell. 1996. Decreased apoptosis in the brain and premature lethality in CPP32-deficient mice. Nature 384: 368-372.

Kumar, S., M. Kinoshita, M. N oda, N.G. Copeland, and N.A. Jenkins. 1994. Induction of apoptosis by the mouse Nedd2 gene, which encodes a protein similar to the product of the Caenorhabditis el egans cell death gene ced- 3 and the mammalian IL-1 $\beta$-converting enzyme. Genes \& Dev. 8: 16131626.

Kwiatkowski, D., T. Stossel, S. Orkin, J. M ole, H. Colten, and H. Yin. 1986. Plasma and cytoplasmic gel solins are encoded by a single gene and contain a duplicated actin-binding domain. Nature 323: 455-458.

Lahti, J.M., J. Xiang, L.S. Heath, D. Campana, and V.J. Kidd. 1995. PITSLRE protein kinase activity is associated with apoptosis. Mol. Cell. Biol. 15: 1-11.

Lazebnik, Y.A., S.H. Kaufmann, S. Desnoyers, G.G. Poirier, and W.C. Earnshaw. 1994. Cleavage of poly(ADP-ribose) polymerase by a proteinase with properties like ICE. Nature 371: 346-347.

Lazebnik, Y.A., A. Takahashi, R.D. Moir, R.D. Goldman, G.G. Poirier, S.H. Kaufmann, and W.C. Earnshaw. 1995. Studies of the lamin proteinase reveal multiple parallel biochemical pathways during apoptotic execution. Proc. Natl. Acad. Sci. 92: 9042-9046.

Lee, N., H. MacDonald, C. Reinhard, R. Halenbeck, A. Roulston, T. Shi, and L.T. Williams. 1997. Activation of hPAK65 by caspase cleavage induces some of the morphological and biochemical changes of apoptosis. Proc. Natl. Acad. Sci. 94: 13642-13647.

Li, F., A. Srinivasan, Y. Wang, R.C. Armstrong, K.J. Tomaselli, and L.C. Fritz. 1997. Cell-specific induction of apoptosis by microinjection of cytochrome $\mathrm{C}$. BCl- $\mathrm{X}_{\mathrm{L}}$ has activity independent of cytochrome c release. J. Biol. Chem. 272: 3029930305.

Li, H., L. Bergeron, V. Cryns, M. Pasternack, H. Zhu, L. Shi, A. Greenberg, and J. Yuan. 1997. Activation of caspase-2 in apoptosis. J. Biol. Chem. 272: 21010-21017.

Li, J., T.R. Billiar, R.V. Talanian, and Y.M. Kim. 1997. Nitric oxide reversibly inhibits seven members of the caspase family via S-nitrosylation. Biochem. Biophys. Res. Commun. 240: 419-424.

Li, P., H. Allen, S. Banerjee, S. Franklin, L. Herzog, C. Johnston, J. M cDowell, M. Paskind, L. Rodman, J. Salfeld, E. Towne, D. Tracey, S. Wardwell, F.-Y. Wei, W. Wong, R. Kamen, and T. Seshadri. 1995. Mice deficient in IL-1 $\beta$-converting enzyme are defective in production of mature IL-1 $1 \beta$ and resistant to endotoxic shock. Cell 80: 401-411.

Li, P., D. Nijhawan, I. Budihardjo, S.M. Srinivasula, M. A hmad, E.S. Alnemri, and X. Wang. 1997. Cytochrome $c$ and dATPdependent formation of A paf-1/caspase- 9 complex initiates an apoptotic protease cascade. Cell 91: 479-489.

Liston, P., N. Roy, K. Tamai, C. Lefebvre, S. Baird, G. ChertonHorvat, R. Farahani, M. M cLean, J.E. Ikeda, A. MacKenzie, and R.G. Korneluk. 1996. Suppression of apoptosis in mammalian cells by NAIP and a related family of IAP genes. Nature 379: 349-353.

Liu, X., C.N. Kim, J. Yang, R. Jemmerson, and X. Wang. 1996. Induction of apoptotic program in cell-free extracts: Requirement for dATP and cytochrome c. Cell 86: 147-157.

Liu, X., H. Zou, C. Slaughter, and X. Wang. 1997. DFF, a heterodimeric protein that functions downstream of caspase 3 to trigger DNA fragmentation during apoptosis. Cell 89: $175-184$.

Loddick, S.A., A. MacKenzie, and N.J. Rothwell. 1996. An ICE inhibitor, z-VAD-DCB attenuates ischaemic brain damage in the rat. NeuroReport 7: 1465-1468.

Loetscher, H., U. Deuschle, M. Brockhaus, D. Reinhardt, P. N elboeck, J. M ous, J. Grünberg, C. Haass, and H. Jacobsen. 1997. Presenilins are processed by caspase-type proteases. J. Biol. Chem. 272: 20655-20659.

Los, M., M. Van de Craen, L.C. Penning, H. Schenk, M. Westendorp, P.A. Baeuerle, W. Dröge, P.H. Krammer, W. Fiers, and K. Schulze-Osthoff. 1995. Requirement of an ICE/ CED-3 protease for Fas/APO-1-mediated apoptosis. Nature 375: 81-83.

Lustig, K.D., T. Stukenberg, T. M cGarry, R.W. King, V.L. Cryns, P. M ead, L. Zon, J. Yuan, and M.W. Kirschner. 1997. Small pool expression screening: a novel strategy for the identification of genes involved in cell cycle control, apoptosis and early development. Methods Enzymol. 283: 83-99.

MacFarlane, M., M. A hmad, S. Srinivasula, T. Fernandes-Alnemri, G. Cohen, and E. Alnemri. 1997a. Identification and molecular cloning of two novel receptors for the cytotoxic ligand TRAIL. J. Biol. Chem. 272: 25417-25420.

MacFarlane, M., K. Cain, X.M. Sun, E.S. Alnemri, and G.M. Cohen. 1997b. Processing/activation of at least four interleukin-1 $\beta$ converting enzyme-like proteases occurs during the execution phase of apoptosis in human monocytic tumor cells. J. Cell Biol. 137: 469-479.

Manji, G.A., R.R. Hozak, D.J. LaCount, and P.D. Friesen. 1997. Baculovirus inhibitor of apoptosis functions at or upstream of the apoptotic suppressor P35 to prevent programmed cell death. J. Virol. 71: 45009-45016.

Mannick, J., K. Asano, K. Izumi, E. Kieff, and J. Stamler. 1994. $\mathrm{N}$ itric oxide produced by human B Iymphocytes inhibits apoptosis and Epstein-Barr virus reactivation. Cell 79: 11371146.

Mannick, J.B., X.Q. Miao, and J.S. Stamler. 1997. Nitric oxide inhibits Fas-induced apoptosis. J. Biol. Chem. 272: 2412524128.

Marsters, S.A., R.M. Pitti, C.J. Donahue, S. Ruppert, K.D. Bauer, and A. Ashkenazi. 1996. Activation of apoptosis by Apo-2 
ligand is independent of FADD but blocked by CrmA. Curr. Biol. 6: 750-752.

M arsters, S.A., J.P. Sheridan, R.M. Pitti, A. Huang, M. Skubatch, D. Baldwin, A. Gurney, A.D. Goddard, P. Godowski, and A. Ashkenazi. 1997. A novel receptor for Apo2L/TRAIL contains a truncated death domain. Curr. Biol. 7: 1003-1006.

Martin, D.A., R.M. Siegel, L. Zheng, and M.J. Lenardo. 1998. Membrane oligomerization and cleavage activates the caspase-8 (FLICE/MACH $\alpha 1$ ) death signal. J. Biol. Chem. 273: 4345-4349.

Martin, S.J., G.A. O'Brien, W.K. Nishioka, A.J. McGahon, A. Mahboubi, T.C. Saido, and D.R. Green. 1995a. Proteolysis of fodrin (non-erythroid spectrin) during apoptosis. J. Biol. Chem. 270: 6425-6428.

Martin, S., C. Reutelingsperger, A. McGahon, J. Rader, R. van Schie, D. LaFace, and D. Green. 1995b. Early redistribution of plasma membrane phosphatidylserine is a general feature of apoptosis regardless of the initiating stimulus: Inhibition by overexpression of $\mathrm{Bcl}-2$ and Abl. J. Exp. Med. 182: 15451556.

Martinou, J., M. Dubois-Dauphin, J. Staple, I. Rodriguez, H. Frankowski, M. Missotten, P. Albertini, D. Talabot, S. Catsicas, C. Pietra, and J. Huarte. 1994. Overexpression of BCL-2 in transgenic mice protects neurons from naturally occurring cell death and experimental ischemia. Neuron 13: 10171030.

Mashima, T., M. Naito, N. Fujita, K. Noguchi, and T. Tsuruo. 1995. Identification of actin as a substrate of ICE and an ICE-like protease and involvement of an ICE-like protease but not ICE in VP-16-induced U 937 apoptosis. Biochem. Biophys. Res. Commun. 217: 1185-1192.

Mayer, B. and B. Hemmens. 1997. Biosynthesis and action of nitric oxide in mammalian cells. Trends Biochem. Sci. 22: 477-481.

McCarthy, N.J., M.K. Whyte, C.S. Gilbert, and G.I. Evan. 1997. Inhibition of Ced-3/ICE-related proteases does not prevent cell death induced by oncogenes, DN A damage, or the Bcl-2 homolog Bak. J. Cell Biol. 136: 215-227.

M edema, J.P., C. Scaffidi, P.H. Krammer, and M .P. Peter. 1998. $\mathrm{BCl}-\mathrm{X}_{\mathrm{L}}$ acts downstream of caspase- 8 activation by the CD95 death-inducing signaling complex. J. Biol. Chem. 273: 33833393.

Minn, A.J., P. Vélez, S.L. Schendel, H. Liang, S.W. Muchmore, S.W. Fesik, M. Fill, and C.B. Thompson. 1997. BCl- $x_{L}$ forms an ion channel in synthetic lipid membranes. Nature 385: 353-357.

Miossec, C., V. Dutilleul, F. Fassy, and A. Diu-Hercend. 1997. Evidence for CPP32 activation in the absence of apoptosis during $T$ lymphocyte stimulation. J. Biol. Chem. 272: 13459-13462.

Miyashita, T., Y. Okamura-Oho, Y. Mito, S. Nagafuchi, and M. Yamada. 1997. Dentatorubral pallidoluysian atrophy (DRPLA) protein cleaved by caspase-3 during apoptosis. J. Biol. Chem. 272: 29238-29242.

Miura, M., H. Zhu, R. Rotello, E.A. Hartwieg, and J. Yuan. 1993. Induction of apoptosis in fibroblasts by IL-1 $\beta$-converting enzyme, a mammalian homolog of the $C$. elegans cell death gene ced-3. Cell 75: 653-660.

Miura, M., R.M. Friedlander, and J. Yuan. 1995. Tumor necrosis factor-induced apoptosis is mediated by a CrmA-sensitive cell death pathway. Proc. Natl. Acad. Sci. 92: 8318-8322.

Mohr, S., B. Zech, E.G. Lapetina, and B. Brüne. 1997. Inhibition of caspase-3 by S-nitrosation and oxidation caused by nitric oxide. Biochem. Biophys. Res. Commun. 238: 387-391.

Muzio, M., A.M. Chinnaiyan, F.C. Kischkel, K. O'Rourke, A. Shevchenko, J. Ni, C. Scaffidi, J.D. Bretz, M. Zhang, R.
Gentz, M. Mann, P.H. Kreammer, M.E. Peter, and V.M. Dixit. 1996. FLICE, a novel FADD-homologous ICE/CED-3like protease, is recruited to the CD95 (Fas/APO-1) deathinducing signaling complex. Cell 85: 817-827.

Muzio, M., G.S. Salvesen, and V.M. Dixit. 1997. FLICE induced apoptosis in a cell-free system. Cleavage of caspase zymogens. J. Biol. Chem. 272: 2952-2956.

Muzio, M., B.R. Stockwell, G.S. Salvesen, and V.M. Dixit. 1998. An induced proximity model for caspase-8 activation. J. Biol. Chem. 273: 2926-2930.

$\mathrm{Na}$, S., T.H. Chuang, A. Cunningham, T.G. Turi, J.H. Hanke, G.M. Bokoch, and D.E. Danley. 1996. D4-GDI, a substrate of CPP32, is proteolyzed during Fas-induced apoptosis. J. Biol. Chem. 271: 11209-11213.

N agata, S. 1997. A poptosis by death factor. Cell 88: 355-365.

N g, F.W.H. and G.C. Shore. 1998. Bcl- $x_{L}$ cooperatively associates with the Bap31 complex in the endoplasmic reticulum, dependent on procaspase-8 and Ced-4 adaptor. J. Biol. Chem. 273: 3140-3143.

N g, F.W.H., M. N guyen, T. Kwan, P.E. Branton, D.W. Nicholson, J.A. Cromlish, and G.C. Shore. 1997. p28 Bap31, a Bcl$2 / \mathrm{BCl}-\mathrm{x}_{\mathrm{L}}-$ and procaspase-8-associated protein in the endoplasmic reticulum. J. Cell Biol. 139: 327-338.

Nicholson, D.W. 1996. ICE/CED-3-like proteases as therapeutic targets for the control of inappropriate apoptosis. Nature Biotechnol. 14: 297-301.

N icholson, D.W. and N. Thornberry. 1997. Caspases: killer proteases. Trends Biochem. Sci. 22: 299-306.

Nicholson, D.W., A. Ali, N.A. Thornberry, J.P. Vaillancourt, C.K. Ding, M. Gallant, Y. Gareau, P.R. Griffin, M. Labelle, Y.A. Lazebnick, N.A. Munday, S.M. Raju, M.E. Smulson, T.-T. Yamin, V.L. Yu, and D.K. Miller. 1995. Identification and inhibition of the ICE/CED-3 protease necessary for mammalian apoptosis. Nature 376: 37-43.

Orth, K., A.M. Chinnaiyan, M. Garg, C.J. Froelich, and V.M. Dixit. 1996a. The CED-3/ICE-like protease Mch2 is activated during apoptosis and cl eaves the death substrate lamin A. J. Biol. Chem. 271: 16443-16446.

Orth, K., K. O'Rourke, G.S. Salvesen, and V.M. Dixit. 1996b. Molecular ordering of apoptotic mammalian CED-3/ICElike proteases. J. Biol. Chem. 271: 20977-20980.

Pan, G., J. Ni, Y.-F. Wei, G.-I. Yu, R. Gentz, and V.M. Dixit. 1997a. An antagonist decoy receptor and a death domaincontaining receptor for TRAIL. Science 277: 815-818.

Pan, G., K. O'Rourke, A.M. Chinnaiyan, R. Gentz, R. Ebner, J. $\mathrm{Ni}$, and V.M. Dixit. 1997b. The receptor for the cytotoxic ligand TRAIL. Science 276: 111-113.

Pan, G., K. O'Rourke, and V.M. Dixit. 1998. Caspase-9, Bcl- $\mathrm{X}_{\mathrm{L}}$, and A paf-1 form a ternary complex. J. Biol. Chem. 273: 58415845.

Piedrafita, F.J. and M. Pfahl. 1997. Retinoid-induced apoptosis and Spl cleavage occur independently of transcription and require caspase activation. Mol. Cell. Biol. 17: 6348-6358.

Quan, L.T., M. Tewari, K. O'Rourke, V. Dixit, S.J. Snipas, G.G. Poirier, C. Ray, D.J. Pickup, and G.S. Salvesen. 1996. ProteoIytic activation of the cell death protease Yama/CPP32 by granzyme B. Proc. Natl. Acad. Sci. 93: 1972-1976.

Rao, L., D. Perez, and E. White. 1996. Lamin proteolysis facilitates nuclear events during apoptosis. J. Cell Biol. 135: 14411455.

Ray, C.A., R.A. Black, S.R. Kronheim, T.A. Greenstreet, P.R. Sleath, G.S. Salvesen, and D.J. Pickup. 1992. Viral inhibition of inflammation: Cowpox virus encodes an inhibitor of the interleukin-1 $\beta$ converting enzyme. Cell 69: 597-604.

Reed, J.C. 1995. Regulation of apoptosis by Bcl-2 family proteins and its role in cancer and chemoresistance. Curr. Opin. On- 
col. 7: 541-546.

Rhéaume, E., L.Y. Cohen, F. Uhlmann, C. Lazure, A. Alam, J. Hurwitz, R.-P. Sékaly, and F. Denis. 1997. The large subunit of replication factor $C$ is a substrate for caspase- 3 in vitro and is cleaved by a caspase-3-like protease during Fas-mediated apoptosis. EMBO J. 16: 6346-6354.

Rossé, T., R. Olivier, L. Monney, M. Rager, S. Conus, I. Fellay, B. Jansen, and C. Borner. 1998. Bcl-2 prolongs cell survival after Bax-induced rel ease of cytochrome c. N ature 391: 496499.

Rothe, M., M.G. Pan, W.J. Henzel, T.M. Ayres, and D.V. Goeddel. 1995. The TNFR2-TRAF signaling complex contains two novel proteins related to baculoviral inhibitor of apoptosis proteins. Cell 83: 1243-1252.

Rotonda, J., D.W. N icholson, K.M. Fazil, M. Gallant, Y. Gareau, M. Labelle, E.P. Peterson, D.M. Rasper, R. Ruel, J.P. Vaillancourt, N.A. Thornberry, and J.W. Becker. 1996. The threedimensional structure of apopain/CPP32, a key mediator of apoptosis. Nature Struct. Biol. 3: 619-625.

Roy, N., M.S. Mahadevan, M. McLean, G. Shutler, Z. Yaraghi, R. Farahani, S. Baird, A. Besner-Johnston, C. Lefebvre, X. Kang, M. Salih, H. Aubry, K. Tamai, X. Guan, P. Ioannou, T.O. Crawford, P.J. de Jong, L. Surh, J.-E. Ikeda, R.G. Korneluk, and A. M acKenzie. 1995. The gene for neuronal apoptosis inhibitory protein is partially deleted in individuals with spinal muscular atrophy. Cell 80: 167-178.

Roy, N., Q. Deveraux, R. Takahashi, G. Salvesen, and J. Reed. 1997. The C-IAP-1 and C-IAP-2 proteins are direct inhibitors of specific caspases. EMBO J. 16: 6914-6925.

Rudel, T. and G. Bokoch. 1997. Membrane and morphological changes in apoptotic cells regulated by caspase-mediated activation of PAK2. Science 276: 1571-1574.

Sakahira, H., M. Enari, and S. N agata. 1998. Cleavage of CAD inhibitor in CAD activation and DNA degradation during apoptosis. Nature 391: 96-99.

Salvesen, G.S. and V.M. Dixit. 1997. Caspases: Intracellular signaling by proteolysis. Cell 91: 443-446.

Schendel, S.L., Z. Xie, M.O. M ontal, S. M atsuyama, M. Montal, and J.C. Reed. 1997. Channel formation by antiapoptotic protein Bcl-2. Proc. Natl. Acad. Sci. 94: 5113-5118.

Schievella, A.R., J.H. Chen, J.R. Graham, and L.-L. Lin. 1997. $M A D D$, a novel death domain protein that interacts with the type 1 tumor necrosis factor receptor and activates mitogenactivated protein kinase. J. Biol. Chem. 272: 12069-12075.

Schneider, P., J. Bodmer, M. Thome, K. Hofmann, N . Holler, and J. Tschopp. 1997a. Characterization of two receptors for TRAIL. FEBS Lett. 416: 329-334.

Schneider, P., M. Thome, K. Burns, J.-L. Bodmer, K. Hofmann, T. Kataoka, N. Holler, and J. Tschopp. 1997b. TRAIL receptors 1 (DR4) and 2 (DR5) signal FADD-dependent apoptosis and activate N F-кB. Immunity 7: 831-836.

Seshagiri, S. and L.K. Miller. 1997a. Baculovirus inhibitors of apoptosis (IAPs) block activation of Sf-caspase-1. Proc. Natl. Acad. Sci. 94: 13606-13611.

- - 1997b. Caenorhabditis elegans CED-4 stimulates CED-3 processing and CED-3-induced apoptosis. Curr. Biol. 7: 455-460.

Shaham, S. and H. Horvitz. 1996. Developing Caenorhabditis elegans neurons may contain both cell-death protective and killer activities. Genes \& Dev. 10: 578-591.

Sheridan, J.P., S.A. Marsters, R.M. Pitti, A. Gurney, M. Skubatch, D. Baldwin, L. Ramakrishnan, C.L. Gray, K. Baker, W.I. Wood, A.D. Goddard, P. Godowski, and A. Ashkenazi. 1997. Control of TRAIL-induced apoptosis by a family of signaling and decoy receptors. Science 277: 818-821.

Shi, L., G. Chen, G. MacDonald, L. Bergeron, H. Li, M. Miura,
R.J. Rotello, D.K. Miller, P. Li, T. Seshadri, J. Yuan, and A. Greenberg. 1996. Activation of an interleukin 1 converting enzyme-dependent apoptosis pathway by granzyme B. Proc. Natl. Acad. Sci. 93: 11002-11007.

Shimizu, S., Y. Eguchi, W. Kamiike, H. Matsuda, and Y. Tsujimoto. 1996. Bcl-2 expression prevents activation of the ICE protease cascade. Oncogene 12: 2251-2257.

Shu, H.-B., M. Takeuchi, and D.V. Goeddel. 1996. The tumor necrosis factor receptor 2 signal transducers TRAF2 and cIAP1 are components of the tumor necrosis factor receptor 1 signaling complex. Proc. Natl. Acad. Sci. 93: 13973-13978.

Song, Q., S.P. Lees-Miller, S. Kumar, Z. Zhang, D.W. Chan, G.C. Smith, S.P. Jackson, E.S. Alnemri, G. Litwack, K.K. Khanna, and M.F. Lavin. 1996. DNA-dependent protein kinase cataIytic subunit: A target for an ICE-like protease in apoptosis. EMBO J. 15: 3238-3246.

Song, Z., K. McCall, and H. Steller. 1997. DCP-1, a Drosophila cell death protease essential for development. Science 275: 536-540.

Spector, M., S. Desnoyers, D. Hoeppner, and M. Hengartner. 1997. Interaction between the $C$. el egans cell-death regulators CED-9 and CED-4. Nature 385: 653-656.

Srinivasan, A., F. Li, A. Wong, L. Kodandapani, R.J. Smidt, J. Krebs, L. Fritz, J. Wu, and K. Tomaselli. 1998. Bcl-X functions downstream of caspase- 8 to inhibit Fas- and tumor necrosis factor receptor 1-induced apoptosis of M CF7 breast carcinoma cells. J. Biol. Chem. 273: 4523-4529.

Srinivasula, S.M., M. Ahmad, T. Fernandes-AInemri, G. Litwack, and E.S. Alnemri. 1996. M olecular ordering of the Fasapoptotic pathway: The Fas/APO-1 protease Mch5 is a CrmA-inhibitable protease that activates multiple Ced-3/ ICE-like cysteine proteases. Proc. Natl. Acad. Sci. 93: 14486-14491.

Srinivasula, S.M., M. Ahmad, S. Ottilie, F. Bullrich, S. Banks, Y. Wang, T. Fernandes-AInemri, C.M. Croce, G. Litwack, K.J. Tomaselli, R.C. Armstrong, and E.S. Elnemri. 1997. FLAME1, a novel FADD-like anti-apoptotic molecule that regulates Fas/TNFR1-induced apoptosis. J. Biol. Chem. 272: 1854218545.

Stamler, J.S. 1994. Redox signaling: Nitrosylation and related target interactions of nitric oxide. Cell 78: 931-936.

Stanger, B.Z., P. Leder, T.-H. Lee, E. Kim, and B. Seed. 1995. RIP: a novel protein containing a death domain that interacts with Fas/APO-1 (CD95) in yeast and causes cell death. Cell 81: $513-523$.

Susin, S.A., N . Zamzami, M. Castedo, E. Daugas, H.-G. Wang, S. Geley, F. Fassy, J.C. Reed, and G. Kroemer. 1997. The central executioner of apoptosis: multiple connections between protease activation and mitochondria in Fas/APO-1/CD95- and ceramide-induced apoptosis. J. Exp. Med. 186: 25-37.

Takahashi, A., E.S. Alnemri, Y.A. Lazebnik, T. Fernandes-AInemri, G. Litwack, R.D. M oir, R.D. Goldman, G.G. Poirier, S.H. Kaufmann, and W.C. Earnshaw. 1996. Cleavage of lamin A by $M c h 2 \alpha$ but not CPP32: Multiple interleukin 1 $\beta$ converting enzyme-related proteases with distinct substrate recognition properties are active in apoptosis. Proc. Natl. Acad. Sci. 93: 8395-8400.

Talanian, R.V., C. Quinlan, S. Trautz, M.C. Hackett, J.A. Mankovich, D. Banach, T. Ghayur, K.D. Brady, and W.W. Wong. 1997. Substrate specificities of caspase family proteases. J. Biol. Chem. 272: 9677-9682.

Tan, X., S. M artin, D. Green, and J. Wang. 1997. Degradation of retinoblastoma protein in tumor necrosis factor- and CD95induced cell death. J. Biol. Chem. 272: 9613-9616.

Tenneti, L., D.M. D'Emilia, and S.A. Lipton. 1997. Suppression of neuronal apoptosis by S-nitrosylation of caspases. Neuro- 
sci. Lett. 236: 139-142.

Teo, M., E. Manser, and L. Lim. 1995. Identification and molecular cloning of a p21cdc42/racl-activated serine/threonine kinase that is rapidly activated by thrombin in platelets. J. Biol. Chem. 270: 26990-26997.

Tewari, M. and V.M. Dixit. 1995. Fas- and tumor necrosis factor-induced apoptosis is inhibited by the poxvirus crmA gene product. J. Biol. Chem. 270: 3255-3260.

Thome, M., P. Schneider, K. Hofmann, H. Fickenscher, E. Meinl, F. Neipel, C. Mattmann, K. Burns, J. Bodmer, M. Schroter, C. Scaffidi, P. Krammer, M. Peter, and J. Tschopp. 1997. Viral FLICE-inhibitory proteins (FLIPS) prevent apoptosis induced by death receptors. Nature 386: 517-521.

Thompson, C.B. 1995. A poptosis in the pathogenesis and treatment of disease. Science 267: 1456-1462.

Thornberry, N., T. Rano, E. Peterson, D. Rasper, T. Timkey, M. Garcia-Calvo, V. Houtzager, P. N ordstrom, S. Roy, J. Vaillancourt, K. Chapman, and D. Nicholson. 1997. A combinatorial approach defines specificities of members of the caspase family and granzyme B. Functional relationships established for key mediators of apoptosis. J. Biol. Chem. 272: 17907-17911.

Thornberry, N.A., H.G. Bull, J.R. Calaycay, K.T. Chapman, A.D. Howard, M.J. Kostura, D.K. Miller, S.M. Molineaux, J.R. Weidner, J. Aunins, K.O. Elliston, J.M. Ayala, F.J. Casano, J. Chin, G.J.-F. Ding, L.A. Egger, E.P. Gaffney, G. Limjuco, O.C. Palyha, S.M. Raju, A.M. Rolando, J.P. Salley, T.-T. Yamin, T.D. Lee, J.E. Shively, M. MacCross, R.A. Mumford, J.A. Schmidt, and M.J. Tocci. 1992. A novel heterodimeric cysteine protease is required for interleukin-1 $\beta$ processing in monocytes. Nature 356: 768-774.

U beda, M. and J.F. Habener. 1997. The large subunit of the DN A replication complex C (DSEB/RF-C140) cleaved and inactivated by caspase-3 (CPP32/YAM A) during Fas-induced apoptosis. J. Biol. Chem. 272: 19562-19568.

Uren, A.G., M. Pakusch, C.J. Hawkins, K.L. Puls, and D.L. Vaux. 1996. Cloning and expression of apoptosis inhibitory protein homologs that function to inhibit apoptosis and/or bind tumor necrosis factor receptor-associated factors. Proc. Natl. Acad. Sci. 93: 4974-4978.

Vanags, D.M., M.I. Porn-Ares, S. Coppola, D.H. Burgess, and S. Orrenius. 1996. Protease involvement in fodrin cleavage and phosphatidylserine exposure in apoptosis. J. Biol. Chem. 271: 31075-31085.

Vander Heiden, M.G., N.S. Chandel, E.K. Williamson, P.T. Schumacker, and C.B. Thompson. 1997. BCl- $x_{L}$ regulates the membrane potential and volume of homeostasis of mitochondria. Cells 91: 627-637.

Vaux, D. 1997. CED-4-The third horseman of apoptosis. Cell 90: 389-390.

Vaux, D.L., S. Cory, and J.M. Adams. 1988. Bcl-2 oncogene promotes haemopoietic cell survival and cooperates with c-myc to immortalize pre-B cells. Nature 335: 440-442.

Vaux, D.L., I.L. Weissman, and S.K. Kim. 1992. Prevention of programmed cell death in Caenorhabditis el egans by human bcl-2. Science 258: 1955-1957.

Verheij, M., R. Bose, X.H. Lin, B. Yao, W.D. Jarvis, S. Grant, M.J. Birrer, E. Szabo, L.I. Zon, J.M. Kyriakis, A. Haimovitz-Friedman, Z. Fuks, and R.N. Kolesnick. 1996. Requirement for ceramide-initiated SAPK/JNK signalling in stress-induced apoptosis. Nature 380: 75-79.

Villa, P., S.H. Kaufmann, and W.C. Earnshaw. 1997. Caspases and caspase inhibitors. Trends Biochem. Sci. 22: 388-393.

Vincenz, C. and V.M. Dixit. 1997. Fas-associated death domain protein interleukin-1 $\beta$-converting enzyme 2 (FLICE2), an ICE/Ced-3 homologue, is proximally involved in CD95- and p55-mediated death signaling. J. Biol. Chem. 272: 65786583.

Vito, P., T. Ghayur, and L. D'Adamio. 1997. Generation of antiapoptotic presenilin-2 polypeptides by al ternative transcription, proteolysis, and caspase-3 cleavage. J. Biol. Chem. 272: 28315-28320.

Wajant, H., F.-J. Johannes, E. Haas, K. Siemienski, R. Schwenzer, G. Schubert, T. Weiss, M. Grell, and P. Scheurich. 1997. Dominant negative FADD inhibits TNFR60-, Fas/A pol- and TRAIL-R/A po2-mediated cell death. Curr. Biol. 8: 113-116. Walczak, H., M .A. Degli-Esposti, R.S. Johnson, P.J. Smolak, J.Y. Waugh, N. Boiani, M.S. Timour, M.J. Gerhart, K.A. Schooley, C.A. Smith, R.G. Goodwin, and C.T. Rauch. 1997. TRAIL-R2: a novel apoptosis-mediating receptor for TRAIL. EMBO J. 16: 5386-5397.

Walker, N.P.C., R.V. Talanian, K.D. Brady, L.C. Dang, N.J. Bump, C.R. Ferenz, S. Franklin, T. Ghayur, M.C. Hackett, L.D. Hammill, L. Herzog, M. Hugunin, W. Houy, J.A. Mankovich, L. McGuiness, E. Orlewicz, M. Paskind, C.A. Pratt, P. Reis, A. Summani, M. Terranova, J.P. Welch, L. Xiong, A. Möller, D.E. Tracey, R. Kamen, and W.W. Wong. 1994. Crystal structure of the cysteine protease interleukin-1 $\beta$-converting enzyme: a (p20/p10)2 homodimer. Cell 78: 343-352.

Wang, L., M. Miura, L. Bergeron, H. Zhu, and J. Yuan. 1994. Ich-1, an Ice/ced-3-related gene, encodes both positive and negative regulators of programmed cell death. Cell 78: 739750.

Wang, S., M. Miuyra, Y.-k. Jung, H. Zhu, E. Li, and J. Yuan. 1998. Murine caspase-11, an ICE-interacting protease, is essential for the activation of ICE. Cell 92: 501-509.

Wang, X., N.G. Zelenski, J. Yang, J. Sakai, M.S. Brown, and J.L. Goldstein. 1996. Cleavage of sterol regulatory el ement binding proteins (SREBPS) by CPP32 during apoptosis. EMBO J. 15: 1012-1020.

Waterhouse, N., S. Kumar, Q. Song, P. Strike, L. Sparrow, G. Dreyfuss, E.S. Alnemri, G. Litwack, M. Lavin, and D. Watters. 1996. Heteronuclear ribonucleoproteins $C 1$ and $C 2$, components of the spliceosome, are specific targets of interleukin $1 \beta$-converting enzyme-like proteases in apoptosis. J. Biol. Chem. 271: 29335-29341.

Wen, L.-P., J. Fahrni, S. Troie, J.-L. Guan, K. Orth, and G. Rosen. 1997. Cleavage of focal adhesion kinase by caspases during apoptosis. J. Biol. Chem. 272: 26056-26061.

Wilson, K.P., J.-A.F. Black, J.A. Thomson, E.E. Kim, J.P. Griffith, M .A. N avia, M .A. M urcko, S.P. Chambers, R.A. Aldape, S.A. Raybuck, and D.J. Livingston. 1994. Structure and mechanism of interleukin-1 $\beta$ converting enzyme. Nature 370: 270275.

Wissing, D., H. Mouritzen, M. Egeblad, G.G. Poirier, and M. Jaattela. 1997. Involvement of caspase-dependent activation of cytosolic phospholipase A2 in tumor necrosis factor-induced apoptosis. Proc. Natl. Acad. Sci. 94: 5073-5077.

Wu, D., H.D. Wallen, and G. N uñez. 1997. Interaction and regulation of subcellular localization of CED-4 by CED-9. Science 275: 1126-1129.

Wyllie, A.H., R.G. Morris, A.L. Smith, and D. Dunlop. 1984. Chromatin cleavage in apoptosis: Association with condensed chromatin morphology and dependence on macromolecular synthesis. J. Pathol. 142: 66-77.

Xia, Z., M. Dickens, J. Raingeaud, R.J. Davis, and M.E. Greenberg. 1995. Opposing effects of ERK and JNK-p38 MAP kinases on apoptosis. Science 270: 1326-1331.

Xiang, J., D.T. Chao, and S.J. Korsmeyer. 1996. BAX-induced cell death may not require interleukin 1 $\beta$-converting enzyme-like proteases. Proc. Natl. Acad. Sci. 93: 14559-14563.

Xue, D. and H.R. Horvitz. 1995. Inhibition of the Caenorhab- 


\section{Cryns and Yuan}

ditis el egans cell-death protease CED-3 by a CED-3 cl eavage site in baculovirus p35 protein. Nature 377: 248-251.

- - . 1997. Caenorhabditis el egans CED-9 protein is a bifunctional cell-death inhibitor. Nature 390: 305-308.

Yang, J., X. Liu, K. Bhalla, C.N. Kim, A.M. Ibrado, J. Cai, T.-I. Peng, D.P. Jones, and X. Wang. 1997. Prevention of apoptosis by $\mathrm{Bcl}-2$ : release of cytochrome $\mathrm{c}$ from mitochondria blocked. Science 275: 1129-1132.

Yaoita, H., K. Ogawa, K. Maehara, and Y. Maruyama. 1998. Attenuation of ischemia/reperfusion injury in rats by a caspase inhibitor. Circulation 97: 276-281.

Yuan, J. and H.R. Horvitz. 1992. The Caenorhabditis elegans cell death gene ced-4 encodes a novel protein and is expressed during the period of extensive programmed cell death. Development 116: 309-320.

Yuan, J., S. Shaham, S. Ledoux, H.M. Ellis, and H.R. Horvitz. 1993. The $C$. el egans cell death gene ced-3 encodes a protein similar to mammalian interleukin-1 $\beta$-converting enzyme. Cell 75: 641-652.

Zamzami, N., P. Marchetti, M. Castedo, D. Decaudin, A. Macho, T. Hirsch, S.A. Susin, P.X. Petit, B. Mignotte, and G. Kroemer. 1995. Sequential reduction of mitochondrial transmembrane potential and generation of reactive oxygen species in early programmed cell death. J. Exp. Med. 182: 367377.

Zamzami, N., P. Marchetti, M. Castedo, T. Hirsch, S.A. Susin, B. M asse, and G. Kroemer. 1996a. Inhibitors of permeability transition interfere with the disruption of the mitochondrial transmembrane potential during apoptosis. FEBS Lett. 384: 53-57.

Zamzami, N., S.A. Susin, P. M archetti, T. Hirsch, I. GómezMonterrey, M. Castedo, and G. Kroemer. 1996b. Mitochondrial control of nuclear apoptosis. J. Exp. Med. 183: 15331544.

Zhivotovsky, B., S. Orrenius, O.T. Brustugun, and S.O. DøskeIand. 1998. Injected cytochrome c induces apoptosis. Nature 391: 449-450.

Zou, H., W. Henzel, X. Liu, A. Lutschg, and X. Wang. 1997. A paf-1, a human protein homologous to C. elegans CED-4, participates in cytochrome c-dependent activation of caspase-3. Cell 90: 405-413. 


\section{Erratum}

Genes \& Development 12: 1551-1570 (1998)

Proteases to die for

Vincent Cryns and Junying Yuan

The authors have discovered an error on p. 1553, left column, second paragraph. The second sentence should read "CED-3 and caspase-1, -2, -4, -5, -8, -9, -10, -11, and -12 all have long prodomains, whereas caspase-3, -6, and -7 have short prodomains." 


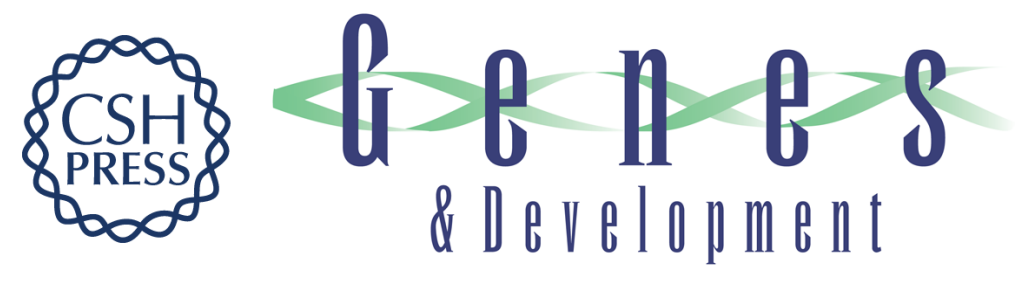

\section{Proteases to die for}

Vincent Cryns and Junying Yuan

Genes Dev. 1998, 12:

Access the most recent version at doi:10.1101/gad.12.11.1551

Related Content Errata for vol. 12, p. 1551

Genes Dev. February , 1999 13: 371

References This article cites 236 articles, 135 of which can be accessed free at: http://genesdev.cshlp.org/content/12/11/1551.full.html\#ref-list-1

Articles cited in:

http://genesdev.cshlp.org/content/12/11/1551.full.html\#related-urls

License Email Alerting
Service $\begin{aligned} & \text { Receive free email alerts when new articles cite this article - sign up in the box at the top } \\ & \text { right corner of the article or click here. }\end{aligned}$

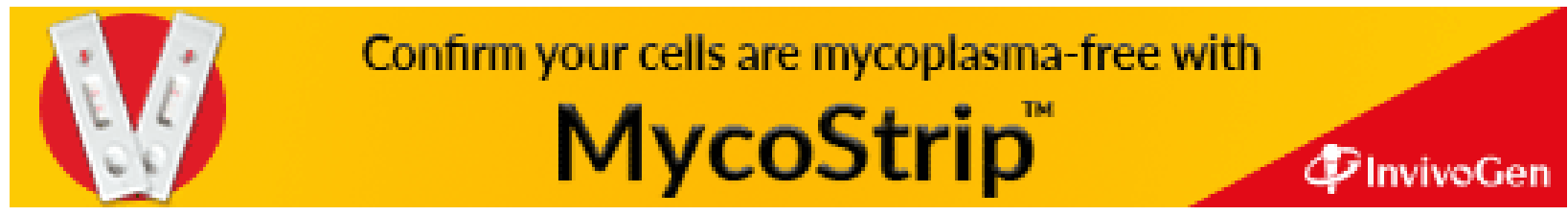

